\title{
Responses of Corn (Zea mays L.) to Zeolite and Urea Fertilizer in Karo Highlands
}

\author{
Riduan Sembiring \\ Quality University of Medan, Faculty Science and Technology, Agrotechnology Study \\ Program, Medan, The Province Sumatera Utara, Indonesia \\ Email: riduan.keloko@gmail.com
}

\begin{abstract}
Swati Sembiring
Quality University of Medan, Faculty Science and Technology, Agrotechnology Study

Program, Medan, The Province Sumatera Utara, Indonesia

Email: swati.sembiring21@gmail.com
\end{abstract}

\begin{abstract}
Seringena Br. Karo
Quality University of Medan, Faculty Science and Technology, Agribusiness Study Program, Medan, The Province Sumatera Utara, Indonesia

Email: seringena.karo@gmail.com
\end{abstract}

Received: May 22, $2020 \quad$ Accepted: June 23, $2020 \quad$ Published: July 6, 2020

doi:10.5296/jas.v8i3.17323 URL: https://doi.org/10.5296/jas.v8i3.17323

\begin{abstract}
The research aims to determine the effects of Zeolites and Urea fertilizer on the production of maize. It was expected that the results of this study could reduce the use of urea fertilizer in producing corn, so that in the buildup to being more efficient and effective, it could also maintain productive soil conditions. The study was conducted from June-December 2017 in Gurusinga Village, Berastagi District, Karo Regency, North Sumatra, Indonesia, in the elevation of 1,250 meters above sea level, flat topography, andosol soil type ( $\mathrm{pH}$ of 5.7). The experimental design was a factorial randomized block design. The first factor was the dose of Zeolite $(\mathrm{Z})$ consisting of $\mathrm{Z} 0=0 \mathrm{~g} /$ plot (control), Z1 = $105 \mathrm{~g} / \mathrm{plot}, \mathrm{Z} 2=210 \mathrm{~g} / \mathrm{plot}, \mathrm{Z3}=$ $315 \mathrm{~g} /$ plot, $\mathrm{Z4}=420 \mathrm{~g} /$ plot. The second factor was Urea fertilizer $(\mathrm{U})$ consisting of $\mathrm{U} 0=0$ $\mathrm{g} /$ plant (control), $\mathrm{U} 1=2.1 \mathrm{~g} /$ plant, $\mathrm{U} 2=4.2 \mathrm{~g} /$ plant, $\mathrm{U} 3=6.3 \mathrm{~g} /$ plant, $\mathrm{U} 4=8,4 \mathrm{~g} /$ plant
\end{abstract}


with 3 replications. The results showed that the Zeolite and Urea fertilizer had a significant effect on the growth of corn plants $(\mathrm{p}<0.05)$ on plant height $(\mathrm{cm})$, stem diameter $(\mathrm{mm})$, and leaf wide $(\mathrm{cm} 2)$, while the number of leaves (strands) had no significant effect ( $\mathrm{p}>0.05)$. Zeolite and Urea fertilizer have a significant effect on the diameter of corncobs, length of corncobs, weight (gross and clean) per (sample and plot) and weight of 100 pieces ( $p<0.05)$, while the number of rows/cob has no significant effect ( $p>0.05)$.

Keywords: corn, zeolite, urea fertilizer, Karo Highlands

\section{Introduction}

Food crops have a crucial role as meeting domestic food, feed, and industrial needs, which tend to increase each year in line with population growth and the development of the food and feed industry so that in terms of National Food Security, the function becomes very important and strategic. Indonesia's population in 2010-2035 is projected to 252.164.800 people, and the total of corn required for direct consumption is 416,071 tons per year (Bappenas 2014). Corn commodity has a very strategic utility, both in the food security system and its role as the driving wheel of the national economy. Corn is used as an ingredient in the food, feed, fuel and polymer (FAO, 2017).

Ibrahim et al. (2012) stated that corn is a fascinating crop model, especially in the fields of biology and agriculture. Since the initiation of the 20th century, the plant has been the object of intensive genetic research and helped form the revolutionary hybrid cultivar technology. In terms of physiology, corn was classified as a $\mathrm{C} 4$ plant hence it is very efficient in utilizing sunlight. In agronomic studies, the dramatic and characteristic response of maize to the deficiency or poisoning of important nutrients makes it a preferred fertilizer physiological experiment plant.

The corn (Zea mays L.) is used as food by humans or animals. In Indonesia, it was listed as the second staple food after rice. In the world, corn recorded as the third staple food after wheat and rice (Sembiring et al., 2016). The value of the corn is commonly in three, foodstuff, animal feed, and industrial raw materials.

In Indonesia, corn is the second important commodity after rice. With the fast-growing livestock industry, however, it is a major component $(60 \%)$ of the feed ration. It was estimated that more than $55 \%$ of domestic corn needs were used for feed, for food consumption about $30 \%$, and the rests were for other purposes such as industries and seeds. The role of corn, therefore, has actually altered; it is more as an industrial raw material than as food (Kasryno, et al., 2016).

The lack of nutrients and water, poor structure, and aeration in the soil were problems of production of maize. The use of balanced fertilizers was also not fully implemented by farmers. It is still become an obstacle to the development of corn (Prima et al., 2015). Despite the land problem, an increase in agricultural production is still faced with low nitrogen fertilizer efficiency. Only about $40 \%$ of urea given to the soil can be utilized by the plants (Widyanto et al., 2013). 
Karo District is one of the corn production areas in North Sumatera. Most if the soil in the region was saturated and has poor nutrients, and then farmers were extremely dependent on inorganic fertilizers. The used of urea fertilizer was around 1 ton/ha could be producing corn of 10-12 tons/ha. The acidity of the land is also unbalanced. It was necessary to add by dolomite before planting. It was functioned to neutralize the $\mathrm{pH}$ of the soil. Corn plants were needed inorganic fertilizers around $450 \mathrm{~kg} / \mathrm{ha}$ Urea, TSP, and KCL fertilizers were $100 \mathrm{~kg} / \mathrm{ha}$, respectively. These fertilizers were quite rare in markets, and their price was high, particularly the non-subsidized one (Sembiring et al., 2016).

The natural zeolite is a mineral formed of volcanic materials in millions of years. In the country, it was spreading along volcanic arcs from Sumatra Island, Java, Nusa Tenggara, and Maluku. It was estimated that more than 50 areas had natural zeolite deposits, with volumes about 400 to 500 million tons. They are generally in the form of clinoptilolite and mordenite (Marfuatun, 2011). It has physical properties with nanometer-sized pores storing water, and chemical properties due to the negative charge on the pore walls occupied by cations and can exchange cations that exist outside the zeolite structure (Winarni et al., 2007).

The micro and macro elements of zeolites were increasing the nutrient of plants. It was also reducing heavy metal poisoning and solubility levels of Fe (iron) and Al (aluminum) ions as well as to release nutrients needed regularly and gradually. It was also reducing the loss of fertilizer due to the use of zeolite water in agricultural land. The recommendation of mixtures of zeolite and urea was 1: 1. Using 30\% of zeolite and $70 \%$ of Urea was widely used by the fertilizer industry. The combinations were thrifty the zeolite with fairly good production (Suwardi. 2009).

The current business of growing corn is the inadequate use of inorganic fertilizers; without it, the productions are fall or even fail. The increasing use of urea was damage to the soil. The study effects of zeolites on reducing urea, therefore, needed to find out.

\subsection{Research Issues}

Can zeolites function as soil amendments, improve land, and expurgated the usage of urea fertilizer, and upsurge yields and the income of corn farmers in the Karo Highlands?

\subsection{Research Hypothesis}

The influence of zeolite as soil ameliorant can expurgate the use of urea fertilizer and the effects of interaction between zeolite and urea to growth and yield of maize in Karo highlands.

The purpose of this study was to find out the optimum dosage of zeolite, the minimum dosage of urea fertilizer, and the effect of interaction between zeolite and urea fertilizer for the efficient use of zeolites on the growth and yield of maize in the Karo highlands.

The benefit of this research was using zeolites to reduce the urea fertilizer in producing maize in the Karo highlands. The findings of the study would become a reference for further research on corn and zeolite. It is also used as materials for community services and as information for farmers in their cultivation practices. 


\section{Literature Review}

Corn (Zea Mays L) is one of the important carbohydrate producing plants in the world besides wheat and rice. Grains of corn is the staple food for people of Central and South America, as for some regions in Indonesia and Africa. Currently, corn is also an important component of animal feed, a source of food oil and cornstarch base ingredients. Various products are using corn as raw materials for various industrial products (Ranum et al. 2014). The corn is growing well in almost any type of soil. It needs loose soil and rich in humus. However, it is not growing properly on solid soil and withstands water because the roots are hard to grow (Magdoff and Van Es, 2009).

The technical cultures and optimum fertilizer are upsurge productions in almost all types of soil with a $\mathrm{pH}$ of 6-7. The corn is not grown appropriately in overly acidic or basic soils ( $\mathrm{pH}$ below 4.5 and over 8.5). However, it special fertilizer is required in such an environment. The critical soil pH for maize was 5.5 (Goulding, 2016).

Meanwhile, the zeolites are a group of hydrated aluminous silicate compounds with the main elements of alkali and alkaline of earth cations and had properties as absorbers, separators, and catalysts. In agriculture, zeolites are used as absorbers, ion exchangers, and soil cleaners, which are leads to fertilizer efficiency and improved production (Al-Jabri, 2010).

The zeolite is being mixed with inorganic fertilizers or organic fertilizers. Using zeolite simultaneously with the right dosage could be maintaining soil moisture for long enough, and when the soil temperature is relatively stable post watering. Meanwhile, compared to the application of fertilizer without mixing with zeolite, the temperature of the soil around the roots upsurges dramatically, which causes the C-organic content to rapidly oxidize, and its availability in the soil could not be maintained longer (Sembiring et al., 2017). It could preserve fertilizers. This proficiency is creating a low cost of fertilizers. However, it is essential to be renowned that it is a companion ingredient for Urea, SP-36, and KCI fertilizers, not to substitute them. Zeolite is also used to reduce the level of pollution of heavy metals such as $\mathrm{Pb}$, $\mathrm{Cd}, \mathrm{Zn}, \mathrm{Cu} 2+, \mathrm{Mn} 2+, \mathrm{Ni} 2+$ in the environment. Modifications of zeolites as adsorbent anions such as NO3-, Cl-, and SO4- have been developed through the process of zeolite-H calculations at 5500C (Sembiring et al; 2017).

The main chemical of zeolite content are $\mathrm{Si0} 2=62.75 \% ; \mathrm{Al} 203=12.71 \% ; \mathrm{K} 20=1.28 \% ; \mathrm{CaO}$ $=3.39 \% ; \mathrm{Na} 2 \mathrm{O}=1.29 \% ; \mathrm{MnO}=5.58 \% ; \mathrm{Fe} 203=2.01 \% ; \mathrm{MgO}=0.85 \% ;$ Clinoptilotite $=30 \%$; Mordernite $=49 \%$. Its CEC value is $80-120 \mathrm{me} / 100 \mathrm{gr}$, and it is abundant for assessing soil fertility. The value of KPK would control the ability of materials to stock fertilizer given previously and it is absorbed by plants (Arryanto et al; 2012).

The functions of zeolites for agricultural are aggregate levels of dissolved oxygen in irrigated water in paddy fields, upholding soil $\mathrm{pH}$ balancing, being able to bind heavy metals that are poisonous to plants such as $\mathrm{Pb}$ and $\mathrm{Cd}$, binding to cations elements in the fertilizers such as $\mathrm{NH} 4$ + from urea, $\mathrm{K}+$ from $\mathrm{KC}$, so that fertilizer absorption becomes efficient and environmentally friendly because it neutralizes the elements that pollute the environment, 
improves soil structure (physical properties) due to $\mathrm{Ca}$ and $\mathrm{Na}$ content and increasing soil CEC (chemical properties) and increasing crop yields (Sembiring et al; 2017).

The corn needs all nutrients, nitrogen $(\mathrm{N})$, phosphorus $(\mathrm{P})$, and potassium $(\mathrm{K})$. The three major elements (three main elements) are usually specified in the form of fertilizers. The plants' intakes of these nutrients are varying depending on the level of soil fertility, environmental conditions, and the state of the plant itself (Sutedjo, 2002).

The productivity of maize depends on the availability of nutrients, especially nitrogen $(\mathrm{N})$. Adding fertilizer of $\mathrm{N}$ (inorganic and organic) to grow and produce maize is commonly practiced in Indonesia. It contributes to a 30-50\% upsurge of maize yield (Erisman et al. 2008; Syafruddin, 2015). The maize absorbs $\mathrm{N}$ nutrients in the upper crop Stover of 5.5-7 kg and seeds of 12.1-14.5 kg to produce one-ton corn (Syafruddin et al. 2006; Syafruddin, 2015). The $\mathrm{N}$ nutrients in corn lost through evaporation are $11-48 \%$, DE nitrification $0.8-1.2 \%$, and $\mathrm{N} 2 \mathrm{O}$ emissions of $0.9-1.7 \%$ of the N-urea dose given to plants (Cai et al. 2002; Syafruddin, 2015). Approximately $15 \% \mathrm{~N}$ of corn is washed in the form of NO3 - (Zhou and Butterbach-Bahl, 2013). N2O and NH3 gas emissions and NO3 leaching - influenced by the dose of $\mathrm{N}$ fertilizer. $\mathrm{N} 2 \mathrm{O}$ evaporation and NO3 leaching - increase exponentially, while NH3 increases linearly with increasing N quantities (Wang et al; 2014a, Syafruddin, 2015).

Lack of nitrogen would be reducing yield. Corn using around 25 percent of all $\mathrm{N}$ needed during the flowering stage. When the corn cobs are formed, $2 / 3$ of all $\mathrm{N}$ needs have been sucked. Urea $(\mathrm{CO}(\mathrm{NH} 2)$ 2) fertilizer contains $46 \%$ nitrogen $(\mathrm{N})$. This fertilizer is very hygroscopic by the high $\mathrm{N}$ content. Urea is very soluble in water and reacts quickly, is also volatile in the form of ammonia (Novizan, 2007)

Fertilization is one of the most important factors of production in addition to land, labor, and capital, balanced fertilization has a role in increasing the yield of corn plants, and fertilizer recommendations are made rationally and balanced based on nutrient requirements in the soil and plant needs for nutrients to increase effectiveness and efficiency fertilizer use and production without causing environmental damage due to excessive fertilization (Tuherkih and Sipahutar, 2008).

Nitrogen is an essential macronutrient whose availability could have a real effect when using inceptisol soils. The nutrient is car-related and results in an easy loss, especially if with improper use, even as a result of almost all the crops both in paddy fields and dry land are in dire need of N nutrient elements (Kasno, 2010). Nitrogen (N) is important to grow corn. During the process of growing and ripening, the seeds are continuously absorbed the nitrogen. It is continuously needed in all stages of growth until the production of seeds. Using the right dose of fertilizer during maize growth cloud be increasing corn yield (Saragih, et al. 2013). The nutrient of $\mathrm{N}$ is car-related and results in an easy loss, especially by improper use. It is vital, either to paddy fields or dryland plants (Kasno, 2010). Nitrogen is a component that is associated with a high photosynthetic activity, strong vegetative growth, and dark green color on the leaves (Ademiluyi, 2015).

Besides, young plants also need a higher percentage of phosphate $(\mathrm{P})$. When the plant is 
deficient of $\mathrm{P}$, it would be observed previously in the knee-high stage. The distribution of phosphate through fertilization, therefore, would be able to stun the situation even though this plant will only take nutrients from the plant to an advanced level. The recommended amount of phosphate fertilizer is around $75 \mathrm{~kg}-100 \mathrm{~kg}$ TSP / ha (SP-36 $200 \mathrm{~kg} / \mathrm{ha}$ ) applied to basic fertilizer (the day before the plant or at the same time planting, all at once. A large amount of potassium will be taken by the plant since the plant is as high as knee until the flowering is finished; a dosage of $\mathrm{K}$ fertilizer of $75-100 \mathrm{~kg} \mathrm{KCl}$ per hectare will be given at the time of planting as base fertilizer in potassium-rich soil, fertilization with potassium can be removed. Fertilizer will be given in the hole made with tugal on the left / right of the seed hole / plant with a distance of $7 \mathrm{~cm}$ and as deep as $10 \mathrm{~cm}$ (Rasyid, B., 2012).

\section{Materials and Research Methods}

- This research was carried out in the Farmer Garden of Gurusinga Village, Berastagi District Karo Regency - North Sumatra. The height of the place is $\pm 1,250$ meters above sea level with flat topography and andosol soil type with a pH of 5.7 from July 2017 to December 2017.

- The ingredients used are Pioner 33 hybrid seeds, zeolites, Urea inorganic fertilizers, TSP $100 \mathrm{~kg} / \mathrm{ha}, \mathrm{KCl} .100 \mathrm{~kg} / \mathrm{ha}$, water.

- Tools used are hoes, rakes, fat, gauges, schlieper, scales, hand sprayers, plywood, plastic ropes, bamboo, saws, machetes, scissors, and stationery.

\subsection{Research Methods}

The study was conducted using factorial randomized block design with 2 treatment factors, as follows:

1. Zeolites, with 5 levels: $Z_{0}=0 \mathrm{~kg} /$ plot (control), $\mathrm{Z}_{1}=105 \mathrm{~g} / \mathrm{plot}, \mathrm{Z}_{2}=210 \mathrm{~g} / \mathrm{plot}, \mathrm{Z}_{3}=$ $315 \mathrm{~g} /$ plot, $\mathrm{Z}_{4}=420 \mathrm{~g} /$ plot.

2. Urea fertilizer 5 levels: $\mathrm{U}_{0}=0 \mathrm{~g} /$ plant (control), $\mathrm{U}_{1}=2.1 \mathrm{~g} /$ plant, $\mathrm{U}_{2}=4.2 \mathrm{~g} /$ plant, $\mathrm{U}_{3}$ $=6.3 \mathrm{~g} /$ plant, $\mathrm{U}_{4}=8.4 \mathrm{~g} /$ plant .

The number of treatment is $5 \times 5=25$ combinations, a number of replications/blocks 3,75 experimental plots, 16 plants/plots, 5 sample plants/plots, spacing is $70 \mathrm{~cm}$ x $30 \mathrm{~cm}$, plot size $350 \mathrm{~cm} \times 150 \mathrm{~cm}$, the distance between plots is $50 \mathrm{~cm}$, the distance between replicates/blocks is $100 \mathrm{~cm}$, land area is 618.75 meters $^{2}$ and 1875 the number of plants to be used.

\section{Research Results and Discussion}

\subsection{Results}

\subsubsection{Plant Height}

The effect of zeolite Urea fertilizer on corn plant height was observed from 2 weeks to 8 weeks after planting (wap) at 1 week intervals with the average observations presented in Table 1. 


\section{Macrothink}

Table 1. Average Plant Height from Influence of Zeolite and Urea in Corn Plants, 2 to 8 wap

\begin{tabular}{cccccccc}
\hline Treatment & 2 wap & 3 wap & 4 wap & 5 wap & 6 wap & 7 wap & 8 wap \\
\hline $\mathrm{Z}_{\mathrm{o}}$ & $11.6 \mathrm{a}$ & $35.9 \mathrm{a}$ & $60.5 \mathrm{a}$ & $96.0 \mathrm{a}$ & $129.5 \mathrm{~b}$ & $157.6 \mathrm{~b}$ & $185.8 \mathrm{c}$ \\
$\mathrm{Z}_{1}$ & $11.6 \mathrm{a}$ & $36.5 \mathrm{a}$ & $61.5 \mathrm{a}$ & $98.7 \mathrm{a}$ & $137.2 \mathrm{ab}$ & $166.4 \mathrm{ab}$ & $195.7 \mathrm{bc}$ \\
$\mathrm{Z}_{2}$ & $11.8 \mathrm{a}$ & $36.6 \mathrm{a}$ & $61.9 \mathrm{a}$ & $100.8 \mathrm{a}$ & $139.8 \mathrm{ab}$ & $169.1 \mathrm{ab}$ & $198.3 \mathrm{abc}$ \\
$\mathrm{Z}_{3}$ & $11.9 \mathrm{a}$ & $37.2 \mathrm{a}$ & $62.5 \mathrm{a}$ & $102.9 \mathrm{a}$ & $143.3 \mathrm{a}$ & $172.4 \mathrm{a}$ & $201.4 \mathrm{ab}$ \\
$\mathrm{Z}_{4}$ & $11.8 \mathrm{a}$ & $37.3 \mathrm{a}$ & $63.5 \mathrm{a}$ & $103.6 \mathrm{a}$ & $143.6 \mathrm{a}$ & $174.0 \mathrm{a}$ & $204.3 \mathrm{a}$ \\
$\mathrm{U}_{0}$ & $11.8 \mathrm{a}$ & $36.1 \mathrm{a}$ & $59.9 \mathrm{a}$ & $94.9 \mathrm{a}$ & $130.0 \mathrm{~b}$ & $158.4 \mathrm{~b}$ & $186.9 \mathrm{~b}$ \\
$\mathrm{U}_{1}$ & $11.8 \mathrm{a}$ & $36.5 \mathrm{a}$ & $61.2 \mathrm{a}$ & $99.6 \mathrm{a}$ & $137.2 \mathrm{ab}$ & $166.4 \mathrm{~b}$ & $195.7 \mathrm{ab}$ \\
$\mathrm{U}_{2}$ & $12.1 \mathrm{a}$ & $36.9 \mathrm{a}$ & $62.3 \mathrm{a}$ & $100.4 \mathrm{a}$ & $138.6 \mathrm{ab}$ & $167.6 \mathrm{ab}$ & $196.5 \mathrm{abc}$ \\
$\mathrm{U}_{3}$ & $11.6 \mathrm{a}$ & $37.3 \mathrm{a}$ & $63.0 \mathrm{a}$ & $102.2 \mathrm{a}$ & $141.3 \mathrm{ab}$ & $170.9 \mathrm{ab}$ & $200.4 \mathrm{ab}$ \\
$\mathrm{U}_{4}$ & $11.4 \mathrm{a}$ & $36.8 \mathrm{a}$ & $63.5 \mathrm{a}$ & $104.9 \mathrm{a}$ & $146.3 \mathrm{a}$ & $176.2 \mathrm{a}$ & $206.0 \mathrm{a}$ \\
\hline
\end{tabular}

Note: Letter notation in the same average column shows no significant difference at the $5 \%$ level in the DMRT Test

The average height of zeolite plants aged 2 to 8 weeks from the results of statistical analysis had no significant effect ( $p>0.05$ ) at 2 to 5 weeks after planting, after 6 weeks of age, the difference was significant ( $\mathrm{p}<0.05)$. Significant differences will be seen in plants at the age of 8 weeks after planting (male flower discharge). At 8 weeks after planting, it was seen that using a zeolite dose of $420 \mathrm{~g} /$ plot $\left(\mathrm{Z}_{4}\right)$, the highest plant height would reach an average of $204.3 \mathrm{~cm}$. The fewer zeolite doses are given, the plant height will decrease. Giving Zeolite as much as 315 $\mathrm{g} /$ plot $\left(Z_{3}\right)$ will be given to plants whose plant height decreases to an average of $201.4 \mathrm{~cm}$, then to use a dose of $210 \mathrm{~g} /$ plot $\left(Z_{2}\right)$ for plants that have an average height of $198.3 \mathrm{~cm}$. The results of the three experiments showed an insignificant height difference ( $p>0.05)$.

Without the use of zeolite $\left(\mathrm{Z}_{\mathrm{o}}\right)$, the lowest plant height is an average of $185.8 \mathrm{~cm}$, with the lowest zeolite administration of $105 \mathrm{~g} /$ plot $\left(Z_{1}\right)$, with a plant height slightly higher than $Z_{0}$ with a plant height at $Z_{1}$ is an average $195.7 \mathrm{~cm}$, where $Z_{o}$ and $Z_{1}$ had no significant relief ( $p>$ 0.05 ) but were significantly different in $Z$ o with respect to $Z_{2}, Z_{3}$ and $Z_{4}(p<0.05$ ).

From the results of this study, the effect of zeolite doses on plant height growth in 8 trials was to use a dose of $210 \mathrm{~g} /$ plot $\left(\mathrm{Z}_{2}\right)$. Based on statistical analysis, the higher the dose of Zeolite given the more noticeable differences, the response curve to plant height with linear equations $\hat{\mathrm{Y}}=0.040 \mathrm{Z}+188.5 \mathrm{r}=0.91$ seen in Figure 1 . 


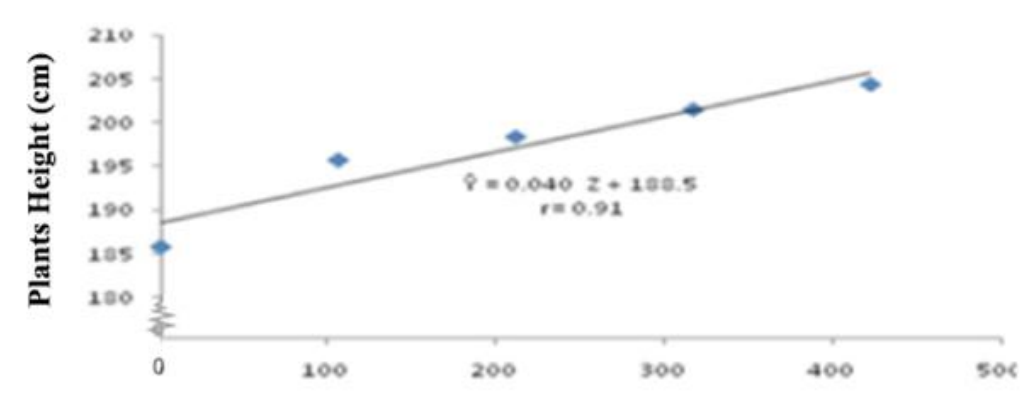

Figure 1. The effect of Zeolit dose towards plants height increased 8 weeks

Average plant height with urea administration, observations were made starting at 2 weeks to 8 weeks after planting. Since the plants were 2 weeks old to 5 weeks, based on the results of statistical analysis, the effect was not significantly different ( $>>0.05$ ), the effect of giving Urea with an increase in plant height increased since the plant was 6 weeks old and began to notice significant differences ( $\mathrm{p}$ ) and the effect is getting real until the plants are 8 weeks old with the use of Urea dosage of $8.4 \mathrm{~g} /$ plant $\left(\mathrm{U}_{4}\right)$ and with the highest average plant height of $205.97 \mathrm{~cm}$, with no significantly lower dose such as giving Urea $6.3 \mathrm{~g} /$ plant $\left(\mathrm{U}_{3}\right)$ average plant height of $200.4 \mathrm{~cm}$, administration of $4.2 \mathrm{~g} /$ plant $\left(\mathrm{U}_{2}\right)$ average height of $196.5 \mathrm{~cm}$, all three will show no significant difference ( $p>0.05)$.

The control treatment (Uo) of the lowest plant height with an average of $186.9 \mathrm{~cm}$ and $\left(\mathrm{U}_{1}\right)$ dose of Urea $2.1 \mathrm{~g} /$ plant with a plant height of $195.7 \mathrm{~cm}$, where Uo and u1 were not significantly different ( $p>0.05$ ) but Uo was significantly different $(p<0.05)$ against $\mathrm{U}_{2}, \mathrm{U}_{3}$ and against $\mathrm{U}_{4}$.

The use of Urea dose at $4.2 \mathrm{~g} /$ plant $\left(\mathrm{U}_{2}\right)$ for the current corn plant height at 8 mst can be used as a recommended dosage and this will be supported by statistical analysis that the higher the dose of Urea used will respond to higher plant heights such as seen in Figure 2.

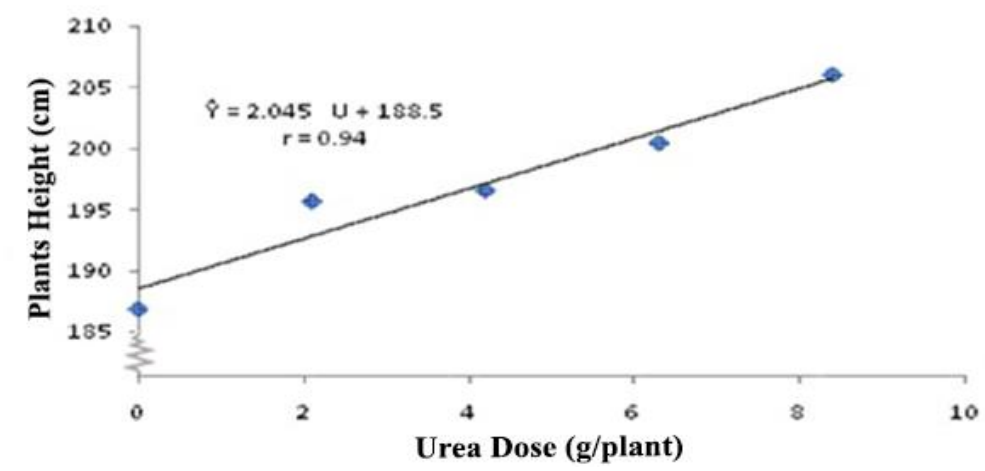

Figure 2. The effect of using urea dose towards plants height increased 8 weeks

The combination treatment with the interaction between the use of zeolite and urea had a different effect that was not significant at $p>0.05$. In this case, it will show the giving of the two factors tested to be mutually beneficial in plant height growth. 


\subsubsection{Rod Diameter}

Data on the results of observations of stem diameter are carried out starting from 2 to 8 weeks after planting (mst) with measurement intervals once a week with the average results presented in Table 2.

Based on statistical analysis since the plants were 2 weeks to 5 weeks, that gave no significant effect ( $p>0.05$ ) on the administration of various doses of zeolite, but after the age of $6 \mathrm{mst}$ the effect of zeolites would provide a significant difference $(\mathrm{p}<0.05)$ to $8 \mathrm{mst}$. Observations on plants aged $8 \mathrm{mst}$ have seen the effect of the increasing use of Zeolite doses and the use of doses of $420 \mathrm{~g} /$ plot $\left(\mathrm{Z}_{4}\right)$ with the highest stem diameter of an average of 3.34 $\mathrm{cm}$. Data on the use of Zeolite doses shows that the smaller the dose is given, the lower the stem diameter of corn plants. It was also seen that the use of Zeolite $315 \mathrm{~g} / \mathrm{plot}\left(\mathrm{Z}_{3}\right)$ on the stem diameter of $3.32 \mathrm{~cm}$ and the use of a dose of $210 \mathrm{~g} /$ plot $\left(Z_{2}\right)$ on the average stem diameter of $3.26 \mathrm{~cm}$ would indicate that where the three treatments $\mathrm{Z}_{4}, \mathrm{Z}_{3}$ and $\mathrm{Z}_{2}$ would provide no significant effect ( $\mathrm{p}>0.05)$.

Table 2. Average Stem Diameter Influence of Zeolite Addition to Corn Plants at 2 to 8 wap

\begin{tabular}{clllllll}
\hline Treatment & 2 wap & 3 wap & 4 wap & 5 wap & 6 wap & 7 wap & 8 wap \\
\hline $\mathrm{Z}_{\mathrm{o}}$ & $1.87 \mathrm{a}$ & $2.45 \mathrm{a}$ & $2.66 \mathrm{a}$ & $2.84 \mathrm{c}$ & $3.03 \mathrm{~b}$ & $3.03 \mathrm{c}$ & $3.21 \mathrm{~b}$ \\
$\mathrm{Z}_{1}$ & $1.99 \mathrm{a}$ & $2.57 \mathrm{a}$ & $2.73 \mathrm{a}$ & $2.90 \mathrm{bc}$ & $3.15 \mathrm{ab}$ & $3.06 \mathrm{c}$ & $3.21 \mathrm{~b}$ \\
$\mathrm{Z}_{2}$ & $1.83 \mathrm{a}$ & $2.41 \mathrm{a}$ & $2.59 \mathrm{a}$ & $2.95 \mathrm{abc}$ & $2.98 \mathrm{ab}$ & $3.10 \mathrm{bc}$ & $3.26 \mathrm{ab}$ \\
$\mathrm{Z}_{3}$ & $1.83 \mathrm{a}$ & $2.41 \mathrm{a}$ & $2.57 \mathrm{a}$ & $2.98 \mathrm{ab}$ & $2.99 \mathrm{a}$ & $3.14 \mathrm{ab}$ & $3.31 \mathrm{ab}$ \\
$\mathrm{Z}_{4}$ & $1.86 \mathrm{a}$ & $2.44 \mathrm{a}$ & $2.61 \mathrm{a}$ & $3.04 \mathrm{a}$ & $3.02 \mathrm{a}$ & $3.21 \mathrm{a}$ & $3.37 \mathrm{a}$ \\
\hline $\mathrm{U}_{\mathrm{o}}$ & $1.91 \mathrm{a}$ & $2.49 \mathrm{a}$ & $2.67 \mathrm{a}$ & $2.83 \mathrm{~b}$ & $3.07 \mathrm{~b}$ & $3.10 \mathrm{c}$ & $3.18 \mathrm{~b}$ \\
$\mathrm{U}_{1}$ & $1.90 \mathrm{a}$ & $2.47 \mathrm{a}$ & $2.62 \mathrm{a}$ & $2.91 \mathrm{ab}$ & $3.03 \mathrm{~b}$ & $3.07 \mathrm{bc}$ & $3.23 \mathrm{~b}$ \\
$\mathrm{U}_{2}$ & $1.92 \mathrm{a}$ & $2.50 \mathrm{a}$ & $2.69 \mathrm{a}$ & $2.97 \mathrm{ab}$ & $3.08 \mathrm{ab}$ & $3.14 \mathrm{abc}$ & $3.31 \mathrm{ab}$ \\
$\mathrm{U}_{3}$ & $1.84 \mathrm{a}$ & $2.42 \mathrm{a}$ & $2.62 \mathrm{a}$ & $2.98 \mathrm{ab}$ & $3.01 \mathrm{ab}$ & $3.15 \mathrm{ab}$ & $3.32 \mathrm{ab}$ \\
$\mathrm{U}_{4}$ & $1.81 \mathrm{a}$ & $2.39 \mathrm{a}$ & $2.55 \mathrm{a}$ & $3.01 \mathrm{a}$ & $2.97 \mathrm{a}$ & $3.17 \mathrm{a}$ & $3.34 \mathrm{a}$ \\
\hline
\end{tabular}

Note: Letter notation in the same average column shows no significant difference at the 5\% level (lowercase) on the DMRT Test

The treatment without zeolite $\left(\mathrm{Z}_{\mathrm{o}}\right)$ at the lowest stem diameter with an average of $3.21 \mathrm{~cm}$ was not significantly different from the $Z_{1}$ treatment at the same average stem diameter.

The effect of urea administration on stem diameter for plants aged 2 to 8 mst will show the results of statistical analysis that the effect is not significantly different $(p>0.05)$ for plants 2 to 5 weeks old, but plants 6 weeks old are seen to have a significant effect ( $\mathrm{p}<0.05$ ). Giving a dose of urea will be more evident in the observation of plants aged $8 \mathrm{mst}$. In 8 -week-old plants, a dose of urea $8.4 \mathrm{~g} /$ plant $\left(\mathrm{U}_{4}\right)$ will be seen, with the highest stem diameter of an average of $3.34 \mathrm{~cm}$ and not significantly different from all uses of the urea dose ( $\mathrm{U}_{3}, \mathrm{U}_{2}$ ). Without the use of urea (Uo) the lowest stem diameter is an average of $3.18 \mathrm{~cm}$, and the use of a low urea dose with $2.1 \mathrm{~g} /$ plant (u1) will have an average stem diameter of $3.23 \mathrm{~cm}$. The treatment of $U_{o}$ was not significantly different from the treatment of low-dose Urea $\left(\mathrm{U}_{1}, \mathrm{U}_{2}\right.$ and $\left.\mathrm{U}_{3}\right)$. 
The treatment carried out in combination with the interaction between the use of zeolite and urea will have a significantly different effect on $p>0.05$. This shows that the giving of the two factors tested will be mutually beneficial to the diameter of the stem.

\subsubsection{Number of Leaves}

Data on the number of leaves of corn plants due to the influence of zeolite and urea administration with observations since the plants were 2 to 8 weeks at 14-day intervals with average results in Table 3 .

Table 3. Average Number of Leaves from Effect of Addition of Zeolites on Corn Plants 2 to 8 weeks

\begin{tabular}{cccccccc}
\hline Treatment & 2 wap & 3 wap & 4 wap & 5 wap & 6 wap & 7 wap & 8 wap \\
\hline $\mathrm{Z}_{\mathrm{o}}$ & $2.04 \mathrm{a}$ & $4.54 \mathrm{a}$ & $7.04 \mathrm{a}$ & $8.82 \mathrm{a}$ & $10.61 \mathrm{a}$ & $2.21 \mathrm{a}$ & $3.81 \mathrm{a}$ \\
$\mathrm{Z}_{1}$ & $2.14 \mathrm{a}$ & $4.58 \mathrm{a}$ & $7.28 \mathrm{a}$ & $9.01 \mathrm{a}$ & $10.74 \mathrm{a}$ & $2.34 \mathrm{a}$ & $3.94 \mathrm{a}$ \\
$\mathrm{Z}_{2}$ & $2.09 \mathrm{a}$ & $4.48 \mathrm{a}$ & $7.28 \mathrm{a}$ & $9.00 \mathrm{a}$ & $10.73 \mathrm{a}$ & $2.15 \mathrm{a}$ & $3.56 \mathrm{a}$ \\
$\mathrm{Z}_{3}$ & $1.97 \mathrm{a}$ & $4.34 \mathrm{a}$ & $6.71 \mathrm{a}$ & $8.43 \mathrm{a}$ & $10.16 \mathrm{a}$ & $1.76 \mathrm{a}$ & $3.36 \mathrm{a}$ \\
$\mathrm{Z}_{4}$ & $2.01 \mathrm{a}$ & $4.42 \mathrm{a}$ & $6.83 \mathrm{a}$ & $8.56 \mathrm{a}$ & $10.28 \mathrm{a}$ & $1.80 \mathrm{a}$ & $3.31 \mathrm{a}$ \\
\hline $\mathrm{U}_{\mathrm{o}}$ & $1.99 \mathrm{a}$ & $4.37 \mathrm{a}$ & $6.76 \mathrm{a}$ & $8.52 \mathrm{a}$ & $10.28 \mathrm{a}$ & $1.88 \mathrm{a}$ & $3.48 \mathrm{a}$ \\
$\mathrm{U}_{1}$ & $2.06 \mathrm{a}$ & $4.52 \mathrm{a}$ & $7.12 \mathrm{a}$ & $8.90 \mathrm{a}$ & $10.68 \mathrm{a}$ & $2.11 \mathrm{a}$ & $3.54 \mathrm{a}$ \\
$\mathrm{U}_{2}$ & $2.08 \mathrm{a}$ & $4.51 \mathrm{a}$ & $7.08 \mathrm{a}$ & $8.81 \mathrm{a}$ & $10.53 \mathrm{a}$ & $2.04 \mathrm{a}$ & $3.54 \mathrm{a}$ \\
$\mathrm{U}_{3}$ & $2.09 \mathrm{a}$ & $4.39 \mathrm{a}$ & $7.09 \mathrm{a}$ & $8.82 \mathrm{a}$ & $10.54 \mathrm{a}$ & $2.14 \mathrm{a}$ & $3.74 \mathrm{a}$ \\
$\mathrm{U}_{4}$ & $2.03 \mathrm{a}$ & $4.56 \mathrm{a}$ & $7.09 \mathrm{a}$ & $8.78 \mathrm{a}$ & $10.48 \mathrm{a}$ & $2.08 \mathrm{a}$ & $3.68 \mathrm{a}$ \\
\hline
\end{tabular}

Note: Letter notation in the same average column shows no significant difference at the 5\% level (lowercase) on the DMRT Test.

Data on the number of leaves on the effect of zeolites on plants aged 2 to 8 days from the results of statistical analysis showed no significant effect ( $p>0.05$ ). The number of leaves since the plants were two weeks after planting (MST) averaged between 1.97 and 2.14 strands due to the influence of zeolites. The number of leaves will increase when the plant is 8 weeks old, between 13.31 to 13.94 strands.

The number of leaves produced when giving urea to plants aged 2 to 8 weeks showed the results of statistical analysis were not significantly different ( $p>0.05)$. The number of leaves in plants that are 2 mst ranges from an average of 1.99 strands to 2.09 strands, and the number of leaves will increase with increasing plant age. When the plant is 8 weeks old, the number of leaves ranges from an average of 13.48 strands to 13.74 strands.

\subsubsection{Leaf Area}

Leaf area data for plants by giving zeolites and urea in plants aged two weeks to 8 weeks after planting (MST) at 7-day intervals (in table 4). The average leaf area when giving zeolite will be different for plants aged 2 weeks to 8 weeks. And since the plants are 2 weeks to 5 weeks old will produce statistical analysis results that are not significantly different ( $p>0.05)$, and have a significant difference after the plants are 6 weeks old $(\mathrm{p}<0.05)$ until the plants are 8 weeks old. Plants 8 weeks old will use a dose of $420 \mathrm{~g}$ zeolite / plot $\left(\mathrm{Z}_{4}\right)$ for a maximum 
area of $2717.31 \mathrm{~cm} 2$. In administering zeolites, it is important to note that the smaller the dose, the lower the leaf area of the plant. It is seen that the effect of administering Zeolite 315 $\mathrm{g} /$ plot $\left(\mathrm{Z}_{3}\right)$ on leaf area $2672.76 \mathrm{~m} 2$, giving Zeolite at a dose of $210 \mathrm{~g} / \mathrm{plot}\left(\mathrm{Z}_{2}\right)$ on an average area of $2644.68 \mathrm{~cm} 2$ and low dose $Z_{1}$ which has an average of $2551.59 \mathrm{~cm} 2$, which the four doses of zeolite will give no significant effect ( $p>0.05$ ).

Without zeolite $\left(\mathrm{Z}_{\mathrm{o}}\right)$ the minimum area is an average of $2384.10 \mathrm{~cm} 2$, with the provision of low Zeolite $105 \mathrm{~kg} /$ plot $\left(\mathrm{Z}_{1}\right)$, the leaf area will look slightly wider when compared to $\mathrm{Z}_{\mathrm{o}}$ with an average $Z_{1}$ that is not significantly different ( $>0.05$ ) but it will be significantly different between $\mathrm{Z}_{0}$ and $\mathrm{Z}_{2}, \mathrm{Z}_{3}$ and $\mathrm{Z}_{4}$.

The results of this study indicate that the effect of zeolite on the leaf area has a recommended dosage of $150 \mathrm{~g} / \mathrm{plot}\left(\mathrm{Z}_{1}\right)$. The results of statistical analysis show that the higher the dose of Zeolite given will give a wider response to leaves with linear equations $\hat{Y}=0.75 \mathrm{Z}+2436$ with $r=0.89$, as shown in Figure 3.

Table 4. Average Leaf Area Effect of Addition of Zeolites in Corn Plants 2 to 8 wap

\begin{tabular}{clllllll}
\hline Treatment & 2 wap & 3 wap & 4 wap & 5 wap & 6 wap & 7 wap & 8 wap \\
\hline Zo & $58.4 \mathrm{a}$ & $223.4 \mathrm{a}$ & $391.2 \mathrm{a}$ & $1168.4 \mathrm{a}$ & $1945.6 \mathrm{c}$ & $2164.8 \mathrm{~b}$ & $2384.1 \mathrm{~b}$ \\
Z1 & $58.7 \mathrm{a}$ & $226.1 \mathrm{a}$ & $393.5 \mathrm{a}$ & $1222.6 \mathrm{a}$ & $2051.8 \mathrm{bc}$ & $2301.7 \mathrm{ab}$ & $2551.6 \mathrm{ab}$ \\
Z2 & $59.7 \mathrm{a}$ & $228.2 \mathrm{a}$ & $399.9 \mathrm{a}$ & $1260.1 \mathrm{a}$ & $2120.4 \mathrm{abc}$ & $2382.5 \mathrm{a}$ & $2644.7 \mathrm{a}$ \\
Z3 & $59.6 \mathrm{a}$ & $230.2 \mathrm{a}$ & $399.4 \mathrm{a}$ & $1264.9 \mathrm{a}$ & $2130.3 \mathrm{ab}$ & $2401.5 \mathrm{a}$ & $2672.8 \mathrm{a}$ \\
Z4 & $59.1 \mathrm{a}$ & $232.0 \mathrm{a}$ & $395.3 \mathrm{a}$ & $1260.5 \mathrm{a}$ & $2125.6 \mathrm{a}$ & $2421.5 \mathrm{a}$ & $2717.3 \mathrm{a}$ \\
\hline Uo & $59.0 \mathrm{a}$ & $227.1 \mathrm{a}$ & $395.2 \mathrm{a}$ & $1190.2 \mathrm{a}$ & $1985.2 \mathrm{a}$ & $2205.9 \mathrm{~b}$ & $2426.5 \mathrm{~b}$ \\
$\mathrm{U} 1$ & $59.6 \mathrm{a}$ & $226.5 \mathrm{a}$ & $399.5 \mathrm{a}$ & $1238.7 \mathrm{a}$ & $2077.9 \mathrm{a}$ & $2337.7 \mathrm{ab}$ & $2597.4 \mathrm{ab}$ \\
$\mathrm{U} 2$ & $60.3 \mathrm{a}$ & $232.0 \mathrm{a}$ & $404.1 \mathrm{a}$ & $1236.4 \mathrm{a}$ & $2068.7 \mathrm{a}$ & $2326.8 \mathrm{ab}$ & $2585.0 \mathrm{a}$ \\
$\mathrm{U} 3$ & $59.0 \mathrm{a}$ & $229.0 \mathrm{a}$ & $395.0 \mathrm{a}$ & $1255.6 \mathrm{a}$ & $2116.2 \mathrm{a}$ & $2383.9 \mathrm{a}$ & $2651.5 \mathrm{a}$ \\
$\mathrm{U} 4$ & $57.6 \mathrm{a}$ & $225.3 \mathrm{a}$ & $385.3 \mathrm{a}$ & $1255.5 \mathrm{a}$ & $2125.6 \mathrm{a}$ & $2417.8 \mathrm{a}$ & $2710.1 \mathrm{a}$ \\
\hline
\end{tabular}

Note: Letter notation in the same average column shows no significant difference at the $5 \%$ level (lowercase) on the DMRT Test

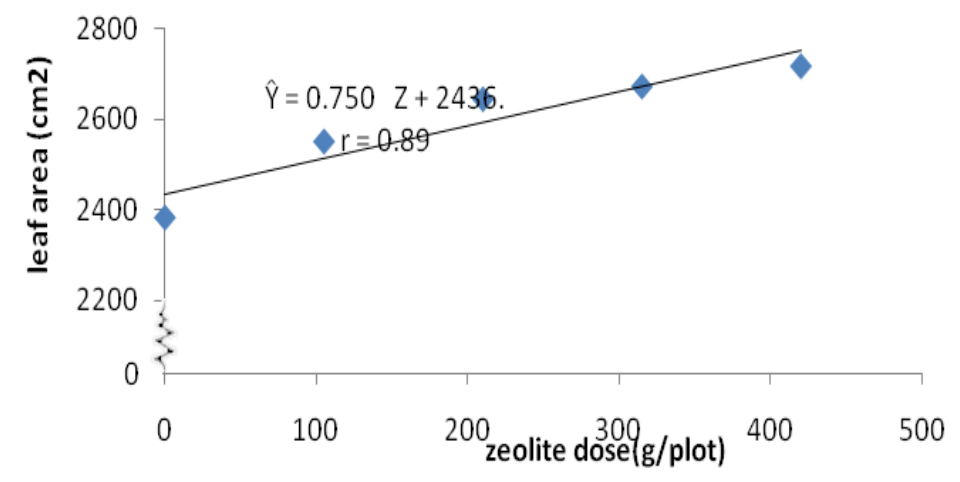

Figure 3. Effect of Zeolite doses on leaf area at $8 \mathrm{mst}$

Data on the average leaf area on the effect of giving several doses of Urea since the plants are 2 to 8 weeks old. Plants that are 2 to 6 weeks old show the results of statistical analysis on the 
effect that is not significantly different ( $p>0.05$ ), after 7 weeks of age the plant will have a significantly different effect $(\mathrm{p}<0.05)$. Data from the results of statistical analysis show that with higher age plants there will be increasingly significant differences. This can be seen in plants that are 8 weeks old. The results of observations on plants aged $8 \mathrm{mst}$, it appears that the influence of the use of Urea doses of $8.4 \mathrm{~g} /$ plant $\left(\mathrm{U}_{4}\right)$ with leaf area that has a maximum average area of $2710.05 \mathrm{~cm} 2$. Thus, this shows that the plant was not significantly different in the use of Urea doses for lower doses of U3. It can be seen that the use of Urea $6.3 \mathrm{~g} /$ plant $\left(\mathrm{U}_{3}\right)$ in plants with an average leaf area of $2651.52 \mathrm{~cm} 2$, then the use of a dose of $4.2 \mathrm{~g} /$ plant $\left(\mathrm{U}_{2}\right)$ on plants with an average leaf area of $2584.99 \mathrm{~cm} 2$ and the use of a dose of $2.1 \mathrm{~g} /$ plants $\left(\mathrm{U}_{1}\right)$ on plants with an average area of $2597.40 \mathrm{~cm} 2$, where all four showed no significant difference $(\mathrm{p}>0.05)$.

Without the use of Urea $\left(U_{o}\right)$, the smallest leaf area is an average of $2426.47 \mathrm{~cm} 2$, and the dose of Urea is low with $2.1 \mathrm{~g} /$ plant $\left(\mathrm{U}_{1}\right)$ with a higher leaf area compared to $\mathrm{U}_{\mathrm{o}}$, where $\mathrm{U}_{\mathrm{o}}$ and $U_{1}$ are not significantly different $(p>0.05)$ whereas Uo was significantly different $(p$ $<0.05$ ) with respect to $\mathrm{U}_{2}, \mathrm{U}_{3}$ and $\mathrm{U}_{4}$.

The effect of the use of urea dose on leaf area increase in plants aged 8 mst using $2.1 \mathrm{~g} /$ plant $\left(\mathrm{U}_{1}\right)$ as the recommended dose, and shows the results of statistical analysis that the higher the dose of urea given, the response to leaf area will be more extensive; with the linear equation $\hat{\mathrm{Y}}=29.58+2469.0 \mathrm{U}$ with $\mathrm{r}=0.86$, seen in Figure 4 .

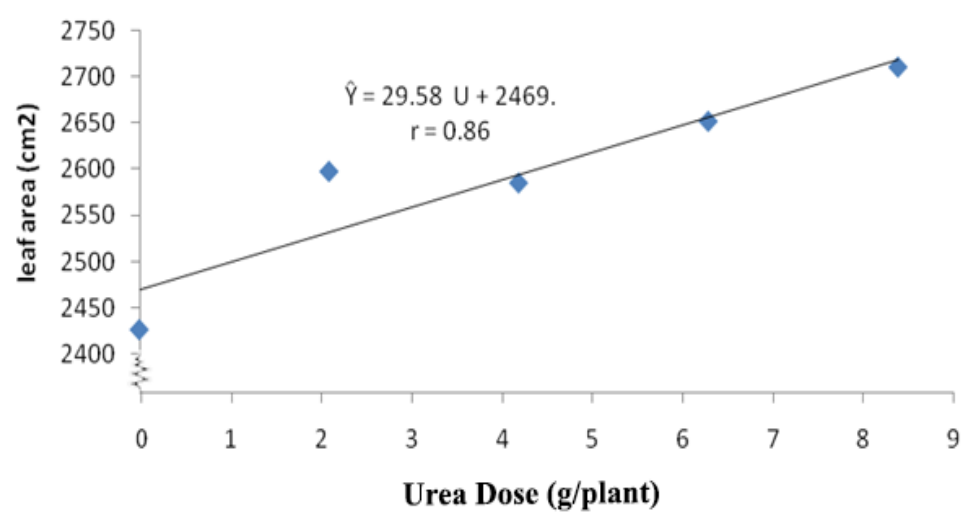

Figure 4. Effect of urea dose on leaf area at 8 wap

The interaction between the use of zeolite and urea doses had a significantly different effect at $p>0.05$ on the leaf area parameters. This case shows the provision of the two factors tested mutually beneficial in the increase in the leaf area of the plant.

\subsubsection{Diameter, Length and Number of Lines / Cobs}

The average measurement results for the diameter of the cobs of corn. The length of corncobs and the number of rows / corncobs had a significantly different effect on zeolite administration and urea dose $(\mathrm{p}<0.05)$ at harvest presented in Table 5. 


\section{Macrothink}

Journal of Agricultural Studies

ISSN 2166-0379

2020, Vol. 8, No. 3

Table 5. Average COB Diameter, COB Length, and Number of Rows / Samples of the Effect of Adding Zeolites and Urea to Corn Plants

\begin{tabular}{cccc}
\hline Treatment & D. Corn cobs $(\mathrm{cm})$ & Long Corncob $(\mathrm{cm})$ & Number of lines/ corncobs (lines) \\
\hline $\mathrm{Z}_{\mathrm{o}}$ & $4.28 \mathrm{~b}$ & $18.15 \mathrm{c}$ & $14.29 \mathrm{a}$ \\
$\mathrm{Z}_{1}$ & $4.35 \mathrm{~b}$ & $18.26 \mathrm{c}$ & $14.44 \mathrm{a}$ \\
$\mathrm{Z}_{2}$ & $4.44 \mathrm{ab}$ & $18.67 \mathrm{bc}$ & $14.65 \mathrm{a}$ \\
$\mathrm{Z}_{3}$ & $4.51 \mathrm{ab}$ & $19.11 \mathrm{ab}$ & $15.27 \mathrm{a}$ \\
$\mathrm{Z}_{4}$ & $4.61 \mathrm{a}$ & $19.90 \mathrm{a}$ & $15.24 \mathrm{a}$ \\
\hline $\mathrm{U}_{0}$ & $4.25 \mathrm{c}$ & $17.92 \mathrm{c}$ & $14.38 \mathrm{a}$ \\
$\mathrm{U}_{1}$ & $4.37 \mathrm{bc}$ & $18.39 \mathrm{bc}$ & $14.29 \mathrm{a}$ \\
$\mathrm{U}_{2}$ & $4.43 \mathrm{abc}$ & $18.83 \mathrm{ab}$ & $14.83 \mathrm{a}$ \\
$\mathrm{U}_{3}$ & $4.53 \mathrm{ab}$ & $19.10 \mathrm{ab}$ & $15.13 \mathrm{a}$ \\
$\mathrm{U}_{4}$ & $4.61 \mathrm{a}$ & $19.85 \mathrm{a}$ & $15.24 \mathrm{a}$ \\
\hline
\end{tabular}

Note: Letter notation in the same average column shows no significant difference at the 5\% level (lowercase) on the DMRT Test

The giving of zeolites (Table 5) on the real effect $(\mathrm{p}<0.05)$ on the diameter of corncobs and the length of corncobs, but not significantly different ( $p>0.05)$ on the number of rows / corncobs. The average diameter of corncobs with the use of several doses of the largest zeolite received treatment using zeolite doses $420 \mathrm{~g} /$ plot $\left(\mathrm{Z}_{4}\right)$ an average of $4.61 \mathrm{~cm}$, followed by treatment giving a dose of $315 \mathrm{~g} /$ plot $\left(\mathrm{Z}_{3}\right)$ an average of $4.5 \mathrm{~cm}$ and treatment use dose of $210 \mathrm{~g} /$ plot $\left(Z_{2}\right)$ with an average diameter of $4.44 \mathrm{~cm}$, the three treatments were not significantly different ( $p>0.05)$. Compared to treatment without Zeolite $\left(Z_{0}\right)$ with the smallest diameter of cob with an average of $4.28 \mathrm{~cm}$ followed and greater with treatment using a dose of $105 \mathrm{~g} /$ plot $\left(Z_{1}\right)$, the average diameter of a cob of $4.35 \mathrm{~cm}$. From the treatment, $Z_{0}$ has no significant difference on $Z_{1}, Z_{2}$ and $Z_{3}$. When compared with the treatment of the use of dose for the diameter of corn cobs which get the optimum diameter by using Zeolite in the treatment $\mathrm{Z}_{2}(210 \mathrm{~g} / \mathrm{plot})$, this can be caused by no significant difference ( $>0.05)$ towards the use of higher doses $\left(Z_{3}\right.$ and $\left.Z_{4}\right)$.

In terms of Zeolite administration, it shows that the higher the zeolite administration, the larger the diameter of the cob and based on statistical analysis, this has a correlation with the linear equation $\hat{Y}=0.0004 Z+4,273$ and $r=0.99$ as shown in Figure 5 .

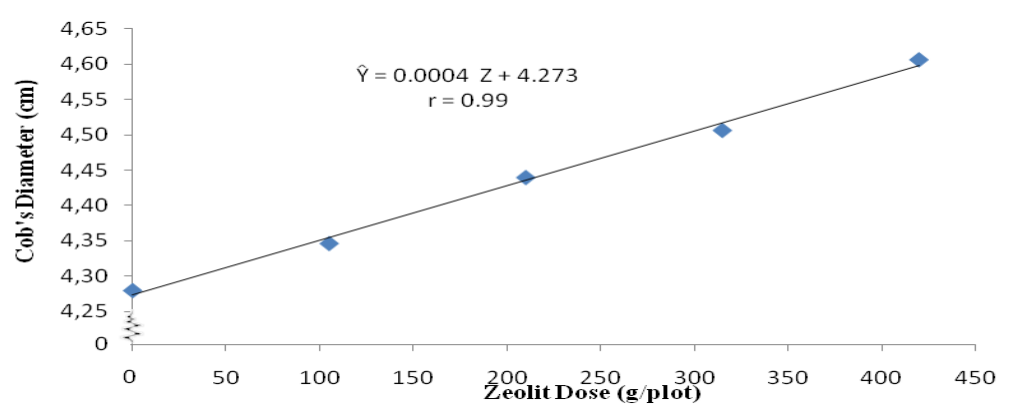

Figure 5. The effect of using Zeolit doses on cob's diameter 


\section{Macrothink}

Giving urea fertilizer with a different dose of influence was not significant $(\mathrm{p}>0.05)$ on the diameter of the cob, giving a dose of $8.4 \mathrm{~g} /$ plant $\left(\mathrm{U}_{4}\right)$ with the highest average diameter of $4.61 \mathrm{~cm}$, followed by the use of urea $6.3 \mathrm{~g} /$ plant $\left(\mathrm{U}_{3}\right)$ diameter $4.53 \mathrm{~cm}$ and $4.2 \mathrm{~g} /$ plant $\left(\mathrm{U}_{2}\right)$ dose on average $4.43 \mathrm{~cm}$ cob, all three were not much different $(\mathrm{p}>0.05)$. Without urea or control $\left(\mathrm{U}_{\mathrm{o}}\right)$ lower, the average $4.25 \mathrm{~cm}$ was not much different from $\mathrm{U}_{1}$ and $\mathrm{U}_{2}$. The greatest result of analysis of ear diameter can use $4.2 \mathrm{~g}$ urea fertilizer / plant $\left(\mathrm{U}_{2}\right)$. Giving the higher dose of urea $(\mathrm{U})$ gives a change in the larger and higher diameter of ear cobs, the higher $\hat{\mathrm{Y}}=$ $0.041 \mathrm{U}+4.26$ and $\mathrm{r}=0.99$ figure 6 .

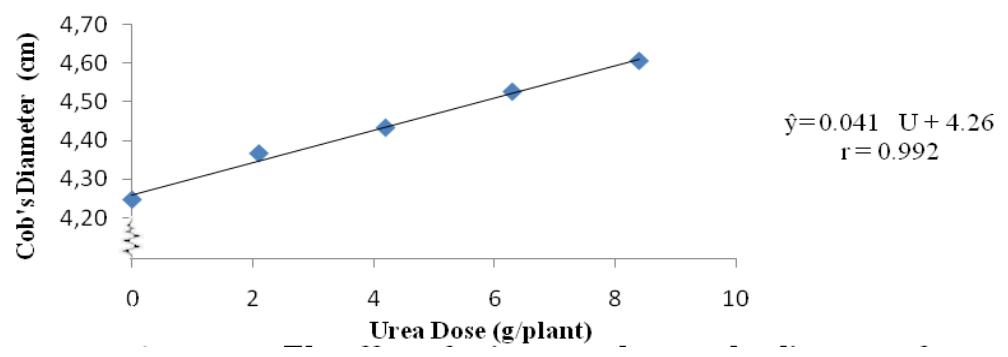

Figure 6. The effect of using urea dose on the diameter of corn cobs

The length of the cobs (Figure 5) measurements at harvest showed a real dose of zeolite (p $<0.05)$ to the length of the cobs, the average administration of high zeolites was Z4 (420 g / plot) the length of the longest cobs of $19.90 \mathrm{~cm}$ did not differ from Zeolite $315 \mathrm{~g} /$ plot $\left(Z_{3}\right)$ on average $19.11 \mathrm{~cm}$, but $Z_{4}$ was much different $(\mathrm{p}<0.05)$ with respect to $Z_{2}, Z_{1}$ and $Z_{0}$. Without Zeolite $\left(Z_{\mathrm{o}}\right)$ the lowest shortest length of cob is $18.15 \mathrm{~cm}$, not much different from $Z_{1}$ and $Z_{2}$ and much different from $Z_{3}$ and $Z_{4}$. The results of the analysis of zeolite $315 \mathrm{~g}$ / plot $\left(Z_{3}\right)$ resulted in optimal cob not much different to $Z_{4}$. The higher Zeolite administration, the higher the cobs length, and the higher the linear statistic with $\hat{Y}=0.004 Z+17.94$ with r-0.93 and shown in Figure 7.

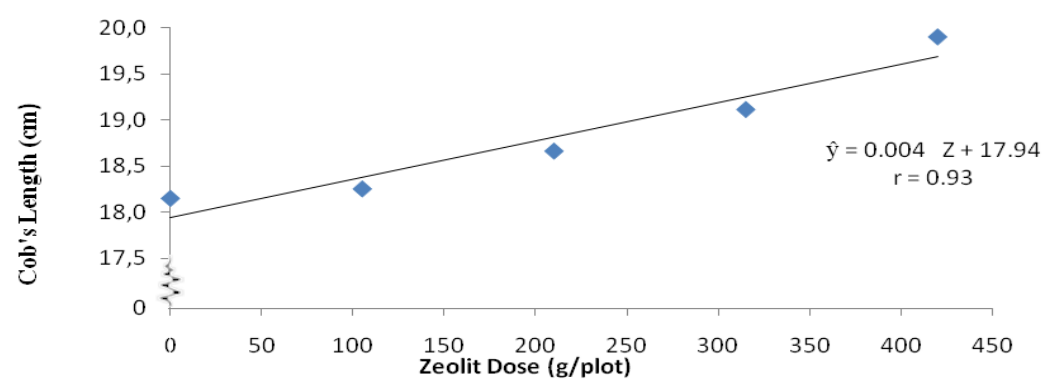

Figure 7. The effect of using Zeolite doses on the length of corn cob

Give urea dose that different much $(\mathrm{p}<0.05)$ on cob length. Giving a dose of $8.4 \mathrm{~g} /$ plant $\left(\mathrm{U}_{4}\right)$ at an average length of $19.85 \mathrm{~cm}$ without significant difference $(\mathrm{p}>0.05)$ to a lower dose of $4.2 \mathrm{~g} /$ plant $\left(\mathrm{U}_{2}\right)$ an average of $18.83 \mathrm{~cm}$ and recommended for the length of cob. The control $\left(U_{o}\right)$ length of the cob was slightly shorter by an average of $17.92 \mathrm{~cm}$ with no significant difference with $U_{1}$, give the higher dose of urea will be effective to the length of the cob and 


\section{Macrothink}

based on statistical analysis obtained a linear equation with $\hat{y}=0.217 \mathrm{U}+17.90 \mathrm{r}=0.98$ Figure 8.

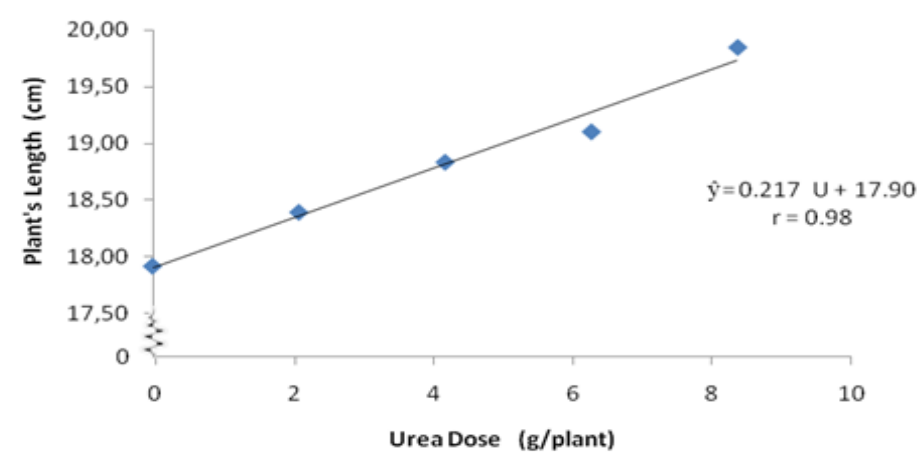

Figure 8. The effect of using urea doses on the length of corn's cob

(Table 5) Zeolite gives no significant effect ( $p>0.05$ ) on the number of rows/cob, the highest average zeolite administration is at $\mathrm{P}_{4}(420 \mathrm{~g} / \mathrm{plot})$ the average number of rows/cob is 15.24 lines, without Zeolite $\left(\mathrm{Z}_{\mathrm{o}}\right)$ with the number of lines/cobs was slightly lower by an average of 14.29 lines, give urea dose has not given significant effect $(p>0.05)$ on the number of rows/cobs, but the high dose of $8.4 \mathrm{~g} /$ plant $\left(\mathrm{U}_{4}\right)$ was 15.24 rows and compared with control $\left(\mathrm{U}_{\mathrm{o}}\right)$ by the number of rows/cobs more low with an average of 14.38 lines.

\subsubsection{Quality (Bruto/ Sample, Bruto / Plot, Net / Sample and Net /Plot)}

Corn shell production has Bruto (g/ sample and $\mathrm{kg} / \mathrm{plot}$ ) and Nett (g/ sample and $\mathrm{kg} / \mathrm{plot}$ ). From the results of weighing the seeds of corn shells, the effect of giving different Zeolites and giving Net/plot at harvest with the average weighing results are presented in Table 6.

(Figure 6) giving Zeolite significant effect ( $\mathrm{p}<0.05$ on gross production/samples (corn cobs and klobot), giving Zeolite $420 \mathrm{~g} /$ plot $\left(\mathrm{Z}_{4}\right)$ high dose treatment with corn gross production / the largest sample with an average of $221.80 \mathrm{~g} / \mathrm{cob}$ followed by the use of Zeolite at a dose of $315 \mathrm{~g} /$ plot $\left(\mathrm{Z}_{3}\right)$ gross weight $212.05 \mathrm{~g} / \mathrm{cob}$ and the use of zeolite $210 \mathrm{~g} /$ plot gross weight $212.41 \mathrm{~g} / \mathrm{cob}$ all showed no significant difference, whereas without Zeolite $\left(\mathrm{Z}_{\mathrm{o}}\right)$ the lowest bruto average income $201.78 \mathrm{~g} / \mathrm{cob}$ was significantly different from $\mathrm{Z}_{4}$.

(Figure 6) shows the apparent Zolite support ( $\mathrm{p}<0.05$ to gross / plot production (corn cobs and klobot), provision of $420 \mathrm{~g} /$ plot $\left(\mathrm{Z}_{4}\right)$ Zeolites in high doses supported by gross average corn / plot production of 11, $15 \mathrm{~kg} /$ plot Zeolite $315 \mathrm{~g} /$ plot $\left(\mathrm{Z}_{3}\right)$ Gross weight $10.83 \mathrm{~kg} / \mathrm{plot}$ and $210 \mathrm{~g}$ zeolite plot / plot $10.69 \mathrm{~kg}$ gross plot / plot are unrealistically different. markedly against $\mathrm{Z}_{3}$ and $\mathrm{Z}_{4}$. 
Table 6. The average of production Bruto and Neto for every sample and plot ( $\mathrm{g}$ and $\mathrm{kg}$ ) From the effect of using Zeolite Doses and Urea Doses on the Corn Cropping

\begin{tabular}{lclcllllll}
\hline Sign & \multicolumn{2}{c}{ Bruto/sampel (g) } & \multicolumn{2}{c}{ Bruto/plot $(\mathrm{kg})$} & \multicolumn{2}{c}{ Net /sampel (g) } & \multicolumn{2}{c}{ Net/plot $(\mathrm{kg})$} \\
\hline $\mathrm{Z}_{\mathrm{o}}$ & 201.78 & $\mathrm{~B}$ & 10.11 & $\mathrm{c}$ & 187.02 & $\mathrm{c}$ & 9.34 & $\mathrm{~b}$ \\
$\mathrm{Z}_{1}$ & 203.75 & $\mathrm{~B}$ & 10.35 & $\mathrm{bc}$ & 187.61 & $\mathrm{bc}$ & 9.41 & $\mathrm{~b}$ \\
$\mathrm{Z}_{2}$ & 212.41 & $\mathrm{Ab}$ & 10.69 & $\mathrm{abc}$ & 195.53 & $\mathrm{abc}$ & 9.68 & $\mathrm{ab}$ \\
$\mathrm{Z}_{3}$ & 212.05 & $\mathrm{Ab}$ & 10.83 & $\mathrm{ab}$ & 199.40 & $\mathrm{ab}$ & 9.74 & $\mathrm{ab}$ \\
$\mathrm{Z}_{4}$ & 221.80 & $\mathrm{a}$ & 11.15 & $\mathrm{a}$ & 204.77 & $\mathrm{a}$ & 10.27 & $\mathrm{a}$ \\
\hline $\mathrm{U}_{\mathrm{o}}$ & 199.57 & $\mathrm{c}$ & 9.92 & $\mathrm{c}$ & 184.08 & $\mathrm{c}$ & 9.10 & $\mathrm{c}$ \\
$\mathrm{U}_{1}$ & 202.71 & $\mathrm{bc}$ & 10.19 & $\mathrm{c}$ & 185.62 & $\mathrm{bc}$ & 9.27 & $\mathrm{c}$ \\
$\mathrm{U}_{2}$ & 208.77 & $\mathrm{abc}$ & 10.44 & $\mathrm{bc}$ & 190.59 & $\mathrm{abc}$ & 9.53 & $\mathrm{bc}$ \\
$\mathrm{U}_{3}$ & 220.48 & $\mathrm{ab}$ & 11.13 & $\mathrm{ab}$ & 204.24 & $\mathrm{ab}$ & 10.07 & $\mathrm{ab}$ \\
$\mathrm{U}_{4}$ & 220.26 & $\mathrm{a}$ & 11.46 & $\mathrm{aa}$ & 209.81 & $\mathrm{a}$ & 10.45 & $\mathrm{a}$ \\
\hline
\end{tabular}

Note: Letter notation in the same average column shows no significant difference at the $5 \%$ level (lowercase) on the DMRT Test.

Net production ( $\mathrm{g} /$ sample or $\mathrm{g} / \mathrm{cob}$ ) Zeolite administration significantly affected $(\mathrm{p}<0.05$ on net production/cob (corncob and klobot), it was seen that giving Zeolite $420 \mathrm{~g} /$ plot $\left(\mathrm{Z}_{4}\right)$ high dose net yield (g / cob ) an average $204.77 \mathrm{~g} / \mathrm{cob}$ of Zeolite $315 \mathrm{~g} /$ plot (Z3) with a gross weight of $199.44 \mathrm{~g} / \mathrm{cob}$ and the use of a zeolite dose of $210 \mathrm{~g} /$ plot with a gross weight of $1199.4 \mathrm{~g} / \mathrm{cob}$ where all three showed no significant difference. (Zo) the lowest gross income is $187.02 \mathrm{~g} /$ ear with significantly different from $\mathrm{Z}_{3}$ and $\mathrm{Z}_{4}$.

Giving Zeolite which is different from the real one ( $\mathrm{p}<0.05$ of net yield / plot, giving Zeolite $420 \mathrm{~g} /$ plot $\left(\mathrm{Z}_{4}\right)$ is a high dose in management with the largest net production/plot with an average of 10, Next $27 \mathrm{~kg} /$ plot Zeolite $315 \mathrm{~g} /$ plot $\left(\mathrm{Z}_{3}\right)$ net weight of $9.74 \mathrm{~kg} /$ plot and zeolite $210 \mathrm{~g} /$ plot net weight of $9.68 \mathrm{~kg} /$ plot all three were not very apparent Without the help of Zeolite $\left(\mathrm{Z}_{\mathrm{o}}\right)$ the lowest average of $9.34 \mathrm{~kg} /$ plot is more significant than $\mathrm{Z}_{4}$.

Data and statistical analysis of Zeolite administration at $210 \mathrm{~g} /$ plot are recommended dose because the higher administration is not significant for $\mathrm{Z}_{3}$ and $\mathrm{Z}_{4}$. The main result is the net production of the broad union, the statistical analysis shows that there is a difference between the use of higher doses of Zeolite which results in a higher net weight resulting in a linear equation $\hat{\mathrm{Y}}=0.002 \mathrm{Z}+9.224$ with $\mathrm{r}=0.89$ with can be used in Figure 9.

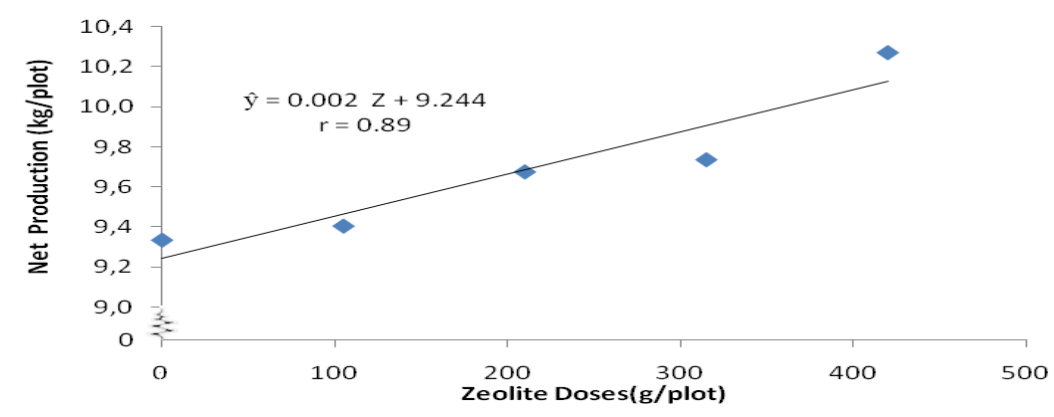

Figure 9. The effect of using Zeolite doses on the net production $(\mathrm{kg} / \mathrm{plot})$ the corn's seed 
Giving different urea doses are given in Table 6. Urea doses significantly affected ( $\mathrm{p}<0.05$ on gross / sample production (corn cobs and klobot), administration of urea $8.4 \mathrm{~g} /$ plant $\left(\mathrm{U}_{4}\right)$ The highest dose of the gross production of maize / average sample $220.26 \mathrm{~g} / \mathrm{cob}$ followed by a dose of $6.3 \mathrm{~g} /$ plant $\left(\mathrm{U}_{3}\right)$ with a gross weight of $220.48 \mathrm{~g} / \mathrm{cob}$ and a dose of urea $4.2 \mathrm{~g} /$ plant with a gross weight of $208.77 \mathrm{~g} / \mathrm{cob}$ where the three are not significantly different, without urea $\left(U_{0}\right)$ the lowest gross weight yield mean $199.57 \mathrm{~g} /$ cob significantly different from $\mathrm{U}_{3}$ and $\mathrm{U}_{4}$.

Figure 6 shows the dose of urea fertilizer which has a significant effect ( $p<0.05$ gross yield/plot (corn cobs and klobot), administration of urea fertilizer $8.4 \mathrm{~g} /$ plant $\left(\mathrm{U}_{4}\right)$ highest dose of gross corn production / average plot of $11.46 \mathrm{~kg} /$ plot followed by dose $6.3 \mathrm{~g} /$ plant $\left(\mathrm{U}_{3}\right) \backslash$ gross weight $11.13 \mathrm{~kg} /$ plot both differences are not significant Without urea $\left(\mathrm{U}_{\mathrm{o}}\right)$ the lowest gross yield is $9.92 \mathrm{~kg} /$ plot significantly different from $\mathrm{U}_{3}$ and $\mathrm{U}_{4}$.

Net production ( $\mathrm{g} / \mathrm{cob}$ ) of urea dose significantly affected ( $\mathrm{p}<0.05$ on net production/cob, urea support at $8.4 \mathrm{~g} /$ plant $\left(\mathrm{U}_{4}\right)$ is a high dose in assistance with net production $(\mathrm{g} / \mathrm{cob})$ of average price average $209.81 \mathrm{~g} /$ cob following the dose of urea fertilizer at $6.3 \mathrm{~g} /$ plant (U3) net weight $204.24 \mathrm{~g} / \mathrm{cob}$ and the dose of urea fertilizer $4.2 \mathrm{~g} /$ plant net weight an average of $190.59 \mathrm{~g} / \mathrm{cob}$ three are not easily different. urea fertilizer (Uo), the average net yield of $184,082 \mathrm{~g} /$ cob was significantly different from $\mathrm{U}_{3}$ and $\mathrm{U}_{4}$, giving urea had a significantly different effect $\left(\mathrm{p}<0.05\right.$ ) on net production/plot, where urea fertilizer $8.4 \mathrm{~g} /$ plant $\left(\mathrm{U}_{4}\right)$ high dose net production/plot yielded the highest average $10.45 \mathrm{~kg} / \mathrm{plot}$ followed by urea dose 6.3 $\mathrm{g} /$ plant $\left(\mathrm{U}_{3}\right)$ net weight of $10.07 \mathrm{~kg} / \mathrm{plot}$, both showing no significant difference ( $\left.\mathrm{p}>0.05\right)$. Whereas without Urea (Zo), the lowest net yield was $9.10 \mathrm{~kg} / \mathrm{plot}$ with a significantly different effect on $\mathrm{U}_{3}$ and $\mathrm{U}_{4}$.

Data and statistical analysis results from the administration of urea $6.3 \mathrm{~g} /$ plant $\left(\mathrm{U}_{3}\right)$ are recommended dosages for cleaner production, where higher doses are not significantly different from $\mathrm{U}_{4}$. Based on the main results is the net production of the broad union, the statistical analysis is between the higher dosage of urea fertilizer yields a higher net weight than the results of linear calculations $\hat{Y}=0.166 \mathrm{Z}+8.986$ with $r=0.964$ with availability can be seen in Figure 10.

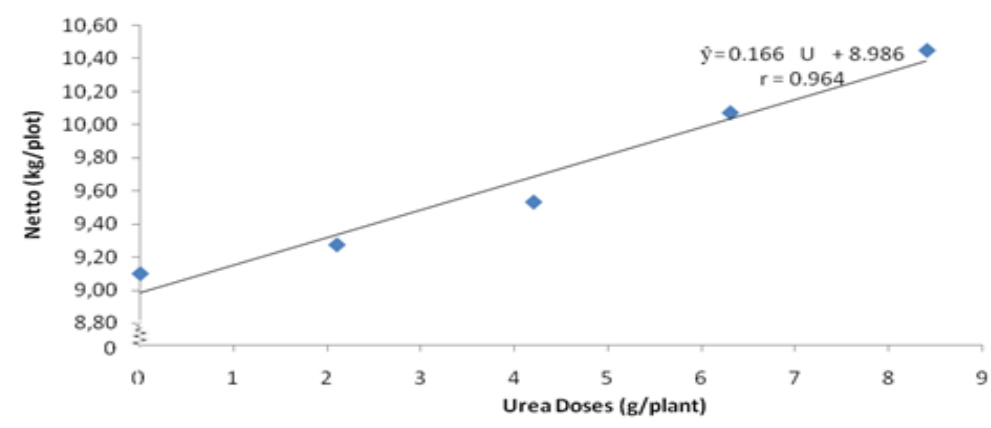

Figure 10. The effect of using urea doses on the net of corn production (kg/plot) 
4.1.7 Pipil Weight (g / Sample, kg/Plot) and Weight of 100 Seeds (g)

Data on Figure 7, give zeolite and urea in which the results of the dipilipil statistical analysis were significantly different ( $\mathrm{p}<0.05)$ to shelled / sample and shelled / plot) and the weight of 100 dried seeds. Zeolite significant effect ( $\mathrm{p}<0.05)$ on the net production of pipettes/samples, giving Zeolite $420 \mathrm{~g} /$ plot $\left(\mathrm{Z}_{4}\right)$ the highest results of pipettes/samples an average of $190.77 \mathrm{~g}$ / sample was not significantly different ( $\mathrm{p}>0.05$ ) on the administration of Zeolite $315 \mathrm{~g} /$ plot $\left(\mathrm{Z}_{3}\right)$ yields an average of $185.66 \mathrm{~g} /$ sample, and administration of Zeolite $210 \mathrm{~g} / \mathrm{plot}\left(\mathrm{Z}_{2}\right)$ an average of $181.53 \mathrm{~g} /$ plot, all three show no significant difference ( $\mathrm{p}>0.05$. These results are giving zeolite $210 \mathrm{~g} / \mathrm{plot}\left(\mathrm{Z}_{2}\right)$ is the recommended dose for shelled production ( $\mathrm{g} /$ sample).

The treatment without Zeolite (Zo) of the lowest pipil yield was an average of $171.66 \mathrm{~g} /$ sample not significantly different ( $\mathrm{p}>0.05$ ) to $\mathrm{Z}_{1}$ (Zeolite $105 \mathrm{~g} / \mathrm{plot}$ ) an average of $174.21 \mathrm{~g}$ / sample, whereas for $\mathrm{Z}_{3}$ and $\mathrm{Z}_{4}$ were significantly different $(\mathrm{p}<0.05)$.

Table 7. the Average of Production on Pipil Net/sample (g), Yeild Pipil/plot (kg) and Weight 100 seeds pipil effected by Zeolit and Urea.

\begin{tabular}{|c|c|c|c|c|c|c|c|}
\hline Sign & Pipi lWeight/samp & & Pipil Weight/plo & & Weight $100 \mathrm{~S}$ & eeds $(g)$ & \\
\hline$Z_{o}$ & 171.66 & $\mathrm{~b}$ & 8.55 & $\mathrm{c}$ & 30.94 & & $\mathrm{~b}$ \\
\hline $\mathrm{Z}_{1}$ & 174.21 & $\mathrm{~b}$ & 8.71 & $\mathrm{bc}$ & 31.49 & & $\mathrm{bc}$ \\
\hline $\mathrm{Z}_{2}$ & 181.53 & $\mathrm{ab}$ & 9.08 & $a b c$ & 32.26 & & $a b c$ \\
\hline $\mathrm{Z}_{3}$ & 185.66 & $\mathrm{ab}$ & 9.28 & $\mathrm{ab}$ & 33.13 & & $\mathrm{ab}$ \\
\hline $\mathrm{Z}_{4}$ & 190.77 & $\mathrm{a}$ & 9.61 & $\mathrm{a}$ & 34.48 & & $\mathrm{a}$ \\
\hline $\mathrm{U}_{\mathrm{o}}$ & 169.62 & $\mathrm{~b}$ & 8.47 & $\mathrm{c}$ & & 31.33 & $\mathrm{c}$ \\
\hline $\mathrm{U}_{1}$ & 172.35 & $\mathrm{~b}$ & 8.62 & $\mathrm{c}$ & & 31.61 & $\mathrm{bc}$ \\
\hline $\mathrm{U}_{2}$ & 176.30 & $a b$ & 8.81 & $\mathrm{bc}$ & & 32.77 & $a b c$ \\
\hline $\mathrm{U}_{3}$ & 188.92 & $a b$ & 9.43 & $\mathrm{ab}$ & & 32.97 & $\mathrm{ab}$ \\
\hline $\mathrm{U}_{4}$ & 196.65 & $\mathrm{a}$ & 9.90 & $\mathrm{a}$ & & 33.61 & $\mathrm{a}$ \\
\hline
\end{tabular}

Note: Letter notation in the same average column shows no significant difference at the $5 \%$ level (lowercase) on the DMRT Test

The results of pipilan (kg/plot) Table 7 administration of different dosages of Zeolite had a significant effect $(\mathrm{p}<0.05)$, Zeolite $420 \mathrm{~g} / \mathrm{plot}\left(\mathrm{Z}_{4}\right)$. The result on the highest of pipilettes / plots was $9.61 \mathrm{~kg} /$ plot not significantly different from $\left(\mathrm{Z}_{3}\right) 315 \mathrm{~g} /$ plot, the result on pipil weight/plot an average of $9.28 \mathrm{~kg} / \mathrm{plot}$ and Zeolite $210 \mathrm{~g} /$ plot $\left(\mathrm{Z}_{2}\right)$ an average of $\left.9.08 \mathrm{~kg} / \mathrm{plot}\right)$ the three gave no significant effect $(p>0.05)$, zeolite $\left(Z_{2}\right)$ it was recommended.

The treatment without Zeolite $\left(Z_{0}\right)$ gives the result of the lowest average pipil weight of 8.55 $\mathrm{kg} / \mathrm{plot}$, not significantly different from $Z_{1}$ and $Z_{2}$. The higher zeolite giving responses to the results of unit area measurements, and the statistical analysis is obtained by the correlation with the linear equation as presented in Figure 11. 


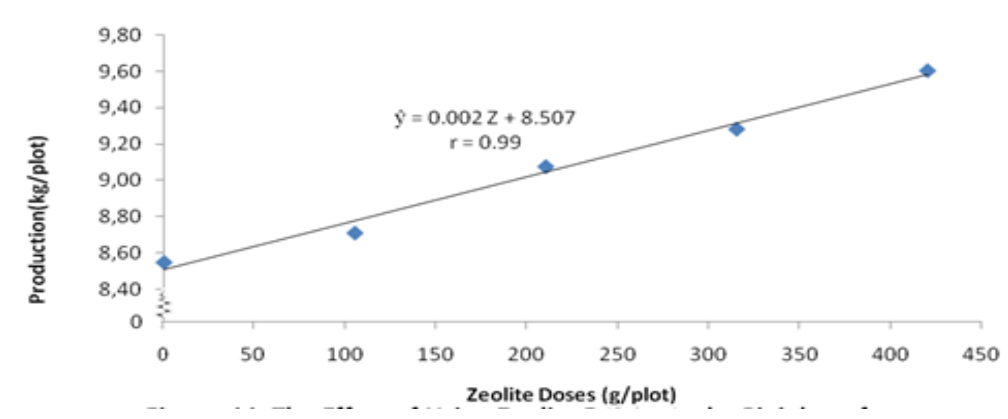

Figure 11. The effect of using Zeolite doses on the pipiplan of production pipilan/plot corn

Gives urea with a different dose can be significantly affected $(\mathrm{p}<0.05)$ on the net weight of the Pipil / sample. Figure 7 net pipette weight / highest sample yield of U4 $8.4 \mathrm{~g} /$ plant with an average of $196.65 \mathrm{~g} /$ sample, followed by $6.3 \mathrm{~g} /$ plant $\left(\mathrm{U}_{3}\right)$ and $4.2 \mathrm{~g} /$ plant $\left(\mathrm{U}_{2}\right)$ and the three samples were not significantly different $(\mathrm{p}>0.05)$. Statistical analysis results that giving urea with the dose is recommended $4.2 \mathrm{~g} /$ plant $\left(\mathrm{U}_{2}\right)$. The treatment of Uo (without urea) results in the lowest average net weight of $169.62 \mathrm{~g} /$ sample, not significantly different from $\mathrm{U}_{1}$ and $\mathrm{U}_{2}$.

Gives urea dry pipilan / plot is the result of various doses of significant effect $(\mathrm{p}<0.05)$. Figure 7. highest yield of pipil / plot $8.4 \mathrm{~g} /$ plant $\left(\mathrm{U}_{4}\right)$ average $9.90 \mathrm{~kg} /$ plot not significantly different ( $p>0.05$ ) to $6.3 \mathrm{~g} /$ plant $\left(\mathrm{U}_{3}\right)$ average $9.43 \mathrm{~kg} /$ plot and $\mathrm{U}_{3}$ dose of urea as a suggestion. The treatment of Uo (without urea) results in the lowest average pipette weight of $8.47 \mathrm{~kg} / \mathrm{plot}$, which is not significantly different from the dose of $2.1 \mathrm{~g} /$ plant $\left(\mathrm{U}_{1}\right)$, average pipette weight of $8.47 \mathrm{~kg} / \mathrm{plot}$, and treatment of $4.2 \mathrm{~kg} / \mathrm{plot}\left(\mathrm{U}_{2}\right)$ and is significantly different against $\mathrm{U}_{3}$ and $\mathrm{U}_{4}$, Gives urea fertilizer will be increased dry shelled results and statistical analysis results that provide equations with linearity as shown in Figure 11.

The results of the data on 100 dried corn kernels (Figure 7) which gave the Zeolite significant effect ( $\mathrm{p}<0.05$ ). The giving of high-dose Zeolite $420 \mathrm{~g} / \mathrm{plot}\left(\mathrm{Z}_{4}\right)$ with the highest of weight of 100 dry seeds on average $34.48 \mathrm{~g}$ was not significantly different from ( $\left.\mathrm{Z}_{3}\right) 315 \mathrm{~g} / \mathrm{plot}$ with an average of $33.13 \mathrm{~g}$ and $\left(\mathrm{Z}_{2}\right) 210 \mathrm{~g} /$ plot with an average of $32.26 \mathrm{~g}$ the three were not significantly different, the treatment without Zeolite (Zo) was the lowest weight of 100 seeds, an average of $30.94 \mathrm{~g}$ was not significantly different $(\mathrm{p}>0.05)$ against $\mathrm{Z}_{1}$, and $\mathrm{Z}_{2}$, give urea fertilizer (figure 7) with a significant effect $(\mathrm{p}<0.05)$ on the net yield of 100 seed pips. Giving a dose of $8.4 \mathrm{~g} /$ plant $\left(\mathrm{U}_{4}\right)$ the highest of result on the weight of 100 seeds on average $33.61 \mathrm{~g}$ was not significantly different from $6.3 \mathrm{~g} /$ plant $\left(\mathrm{U}_{3}\right)$ an average of $32.97 \mathrm{~g} / 100$ seeds and $4.2 \mathrm{~g}$ urea/plant $\left(\mathrm{U}_{2}\right)$ on an average of $32.77 \mathrm{~g} / 100$ of the three seeds was not significantly different. Without urea (Uo) weight of 100 seeds, the lowest average of $31.33 \mathrm{~g}$ was not significantly different $(\mathrm{P}>0.05)$ with $2.1 \mathrm{~g} /$ plant $\left(\mathrm{U}_{1}\right)$ and a dose of $4.2 \mathrm{~g} /$ plant $\left(\mathrm{U}_{2}\right)$, but Uo was significantly different $(\mathrm{p}<0.05)$ it against $\mathrm{U}_{3}$ and $\mathrm{U}_{4}$.

\section{Discussions}

\subsection{The Effect of Zeolite Doses on the Growth of Corn Crop}

Data analysis of various parameters of Zeolite influence significantly affects the growth of 
corn. Different zeolites had effects significantly different $(\mathrm{p}<0.05)$ on plant height, stem diameter, and leaf area. But it was not significantly different ( $p>0.05)$ on the number of leaves.

The growth vegetative requires a huge supply of nitrogen for the formation of biomass that comes from availability in soil or through fertilization (Kuruseng Haris and Kuruseng Askari Moh., 2008).

Zeolite can reduce to gives fertilizer and also soil acidity by increasing growth and production. It is known that Zeolite is a collection of hydrated aluminosilicates with the main elements consisting of alkali and alkaline earth and have properties as absorbers, separators, and catalysts. In agriculture, zeolites are used as absorbers, ion exchangers and soil cleaners which lead to fertilizer efficiency and increased production (Suwardi, 2009). Giving Zeolite is one of the factors to increase plant growth. The availability of nutrients can be increased with the nutrient absorption response on plant roots. The low zeolite has given to plants that cause soil nutrients to be low, causing stunted outgrowth and the result of maize (Afendi, MR., 2016).

Gives zeolites on soils that have low KTK such as Oxisol, Ultisol, and some Inceptisol can increase KTK. Zeolite is given to the soil because zeolite has a high nutrient absorption capacity, especially $\mathrm{K}$ and $\mathrm{NH} 4$, the ability of the soil is bind to these elements that can be increased. The reduction of nitrogen is loss either with washing or nitrification can increase crop production (Rasyid, B., 2012).

The capacity of exchange on Zeolite is very able to regulate the release of nutrients and can reduce damage to plant roots due to good aeration and improve the nitrification process. The use of zeolites can be streamlined fertilization, especially the use of urea and reduce damage to excessive watering intensity. This is due to zeolites able to absorb nutrients and redistribute them and be able to maintain moisture for a longer time (Suwandi, 2000; Widyanto, 2013).

\subsection{The Effect Of The Using Urea Doses On The Growth of Corn Crop}

Statistical analysis data obtained the average variation of the parameters of urea fertilizer on corn plants significantly affected $(\mathrm{p}<0.05)$ on growth. Different doses of urea fertilizer give different responses to growth in the field. The parameters show significant differences for plant height, stem diameter. The higher dose of urea provides stimulation to the growth of corn faster. Because plant growth during vegetative growth requires a large supply of nitrogen for biomass formation (Widyanto. A., et al., 2013)

Heard, J. (2004) added that fertilizer application to plants entering the vegetative period would increase growth and increase in the number of cells, nutrient uptake included nitrogen, which is one of the cell components and macromolecular formation, to increase the quality of stronger stems to reduce resistance to cracks.

The higher application of urea fertilizer to plants increases the availability of nutrients, according to opinion Sutedjo, M. M., (2008) stating the need for nutrients for each phase of plant growth is different. Urea fertilizer is a fertilizer containing $45-46 \% \mathrm{~N}$, is very soluble in 
water and reacts quickly, is also easily converted into ammonium ions $(\mathrm{NH} 4+)$ that can be absorbed by plants (Sutedjo, M. M., 2002).

This is in agreement Nur Aina et al., 2017) states that in good environmental conditions to carry out photosynthesis can produce $(60-80) \%$ of the assimilate results are translated into other plants in the organs of growth and production. Growth and production will increase if supported by environmental factors such as light and water (Bunyamin and Aqil, 2009), (Heard, J., 2004) but at the time of this study, water could not need to be fulfilled because at the time of this study it coincided with the start of the dry season when the plant growth phase had a lack of water, so the growth and production of plants do not get maximum results.

The statement is confirmed by Bunyamin Z, et al. (2012) that corn is a plant that is very sensitive to fertilization, deficiency or excess of one type of macroelements will cause physiological changes in plants. $\mathrm{N}$ absorption by maize takes place during its growth, therefore, to obtain good results, macro and micronutrients in the soil must be sufficiently available during the growth phase.

\subsection{Effect of Zeolite and Urea Interaction in Soil Improvement of Corn Growth}

The results of the analysis of variance showed that there were no significantly different interactions between the treatments of all vegetative parameters observed. The administration of Zeolite and urea on growth and yield of maize were not significantly different ( $p>0.05$ ). Zeolite can reduce urea in the field, both factors tested on plants support each other, due to the formation of roots in maize plants supported by adequate nutrient content in the soil during planting.

Plants that grow must contain $\mathrm{N}$ in forming new cells. Photosynthesis produces carbohydrates from $\mathrm{CO} 2$ and $\mathrm{H} 2 \mathrm{O}$, but the process cannot take place to produce proteins, nucleic acids, and so on when $\mathrm{N}$ is not available. Severe $\mathrm{N}$ deficiency will stop the process of growth and reproduction. $\mathrm{N}$ deficiency is one cause of plants becoming stunted (Sabilu, Yusuf, 2016). The use of zeolites in ultisol soils can work to improve the quality of fertilizer use, mixtures to make fertilizer available slowly, soil moisturizers and control water reserves. Natural zeolites have a very good ability to absorb and exchange cations (Afendi, MR. et al., 2016).

The results of research on rice showed that zeolite administration could increase yield. The highest concentration of $\mathrm{N}$ and $\mathrm{K}$ absorbed by rice plants at the age of 6 MST on zeolite treatment was $125 \mathrm{~kg}$ ha- 1 . The uptake of $\mathrm{N}$ decreases as the zeolite dose increases, this shows that more $\mathrm{N}$ enters the zeolite pores and will be released slowly back to be absorbed by plants (Al-Jabri 2010). The results of the study Yateman Arryanto, et al. (2012) combined zeolite dose of $750 \mathrm{~kg} / \mathrm{ha}$ with urea dose of $50 \mathrm{~kg} / \mathrm{ha}$ showed the best results on leaf area, plant height, and total dry weight/plant compared with the treatment of urea dose of 300 $\mathrm{kg} / \mathrm{ha}$ without zeolite administration.

\subsection{The Effect of the Using Zeolite Doses on the Corn Cropping}

The results of the analysis of variance have a significant effect on production per plant or 
production per plot. But it shows no significant difference $(\mathrm{p}>0.05)$ to the weight of 100 corn seeds. zeolite, which will then be released again according to plant needs.

The use of zeolite is to be able to absorb gas molecules such as $\mathrm{CO}, \mathrm{CO} 2, \mathrm{H} 2 \mathrm{~S}$. Zeolites are non-metallic minerals or industrial minerals, have physical and chemical properties, namely as absorbers, ion exchangers, molecular filters and as a catalyst (Kusdarto, 2008) 40. Zeolite as a soil enhancer is a mineral of a hydrated aluminosilicate compound with a hollow structure and contains interchangeable alkali cations. Zeolite, as a fixer that is given into the soil in relatively large quantities can improve the physical, chemical, and biological properties of the soil so that agricultural production can be increased (Al-Jabri, M. 2010).

The proper use of zeolite uses $210 \mathrm{~g} /$ plot $\left(\mathrm{Z}_{2}\right)$. This is by the results of the study (Al-Jabri M. and R. Soegianto, 2014). Give Zeolites is one factor in increasing the availability of nutrients needed by plants. The potential of zeolites in Indonesia, the chemical and physical properties of zeolites, the use of zeolites in improving the chemical and physical properties of ultisol soils, the use of zeolites in increasing crop production (Kusdarto, 2008).

Increased corn yield of $6-11 \%$, soybean $19 \%$, peanuts $18 \%$, and tomatoes $35 \%$ proves that the physical, chemical, and biological properties of the soil can be improved with zeolites. $\mathrm{N}$ accumulation of $\mathrm{N}$ fertilizer is twice as high compared to control if zeolite is given 3 and 6 tons / ha, this is because the conversion of NH4 + to NO3 - as much as $30-40 \%$ can be inhibited by zeolites (Al-Jabri, M. 2010).

\subsection{The Effect of the Using Urea Doses on the Corn Cropping}

The statistical analysis of observations in the field of variance in the average observations of parameters from the use of urea fertilizer doses on the corn is significantly different $(p<0.05)$ on the corn crop. Give urea with different doses to the result of the corn crop in the field. The parameters show a real difference $(\mathrm{p}<0.05)$ obtained gross and net results per sample or plot, resulting in a significant difference in effect on Pipil / sample results and per plot.

Setyo Budi et el., (2015) explains the function of nitrogen $(\mathrm{N})$ for plants is to accelerate plant growth, increase plant height, and stimulate budding by the results of this study which shows the response of plant height and weight of corn canopy to Urea fertilizer is relatively greater than the response of plants to other fertilizers.

Plants absorb $\mathrm{N}$ when plants are active, but not always at the same level of need. The amount of $\mathrm{N}$ that can be absorbed every day per unit weight of the plant is maximum when it is still young and gradually decreases with increasing plant age. Nitrogen is the main constituent of the dry weight of young plants compared to older plants. Nitrogen must be available in plants before new cells are formed (Sabilu, Yusuf. 2016).

The yield in the form of seeds of urea fertilizer is best using $6.3 \mathrm{~g} /$ plant $(150 \mathrm{~kg} / \mathrm{ha})$, according to the results of the study Nur Aina et al. (2017) that the recommended dosage for growth and production of $150 \mathrm{~kg} / \mathrm{ha}$ corn plants is slightly lower which is planted in the highlands with a recommendation of $4.2 \mathrm{~g} /$ plant $\left(\mathrm{U}_{2}\right)$. Based on the use of the higher dose of urea fertilizer given to plants is the availability of elements in growth, this is by the opinion 
(Kresnatita S. et el. 2013) stating the nutrient requirements for each phase of plant growth is different (Sutedjo, M. M., 2000).

\subsection{The Effect of the Zeolite Interaction and Urea on the Corn Cropping}

Based on the results of the analysis and presented in a variety show that there is no significant interaction ( $p>0.05$ ) between the treatment of the use of Zeolite doses and the dose of urea fertilizer on all parameters (maize production).

The administration of Zeolite and urea to the soil in the corn crop showed in the production showed that the interaction of different was not significant ( $p>0.05$ ), but the two plants tested on the plants were mutually supportive. This is due to the use of zeolite and urea doses do not show significant differences. With catalyst with the addition of zeolite and urea doses can overcome the nutrient requirements by plants. This situation is caused by the formation of roots in maize plants supported by sufficient nutrient content in the soil during planting in the field. By the availability of sufficient nutrients in the soil in plants followed by greater production (Al-Jabri, M. 2010).

Plants given zeolite + urea have stem circumference, leaf color intensity, ear weight, wet and dry crown weights, wet and dry root weights are better than other treatments (Polat et al., 2004). According to (Sembiring, et el. (2017) the effect of using Nitrogen (N) on the quality and quantity of yields is the refinement of the process of filling the seeds in full so that it can harden and prevent seed downsizing at the tip of the cob, this is positively correlated with the weight of the cob on corn plants.

Give zeolite in soil that has a cation exchange capacity (CEC) is low so that it can increase soil CEC. According to Polat et al., (2004) and Heard, J. (2004) Zeolites are given to the soil because zeolites have nutrient absorption capacity, especially Potassium (K) and Ammonium (NH4), the ability of the soil to bind these elements can increase. The reduction of nitrogen loss either from washing or nitrification can increase crop production.

Increased production due to zeolite administration is due to an increase in nitrogen efficiency, especially in reducing nitrate leaching. The use of zeolites 3 and 6 tons/ha results in higher nitrogen accumulation compared to controls treated with $\mathrm{N}$ fertilizer twice. Zeolites can inhibit the conversion of NH4 to nitrate by $30-40 \%$ (Suwandi. 2000).

The results of the study Yateman Arryanto et al. (2012) combined zeolite dose of $750 \mathrm{~kg} / \mathrm{ha}$ with urea dose of $50 \mathrm{~kg} / \mathrm{ha}$ showed the best results on leaf area, plant height, and total dry weight/plant compared with the treatment of urea dose of $300 \mathrm{~kg} / \mathrm{ha}$ without zeolite administration. Giving zeolite at a dose of $500 \mathrm{~kg} / \mathrm{ha}$ can increase cob yield compared to plants without zeolite administration.

Suwardi. (2009) from the results of his research and showed that zeolite application and organic fertilizer dosages significantly affected plant height, leaf area, production/sample, production/plot. The best treatment of zeolite was $\mathrm{Z}_{2}(945 \mathrm{~g} /$ plot $)$ and urea $\mathrm{U}_{1}$ fertilizer (4.2 $\mathrm{g} /$ plant). Based on the results of research that has been done namely the growth response of corn (Zea mays) by giving zeolite coated urea as slow-release nitrogen, it can be concluded 
that the weight of the cob and the length of the cob showed different results to other treatments using the application of zeolite coated urea with a concentration of $10 \%$ (Sembiring, et el., 2017).

\section{Conclusions and Suggestions}

\subsection{Conclusions}

Give some Zeolite doses has a real effect in plant's height, rod's diameter, and leaves' wide but not significantly different in leaves' number, weight in 100 seeds to produce a vegetative growth and result from the good height used doses $210 \mathrm{~g} / \mathrm{plot}\left(\mathrm{Z}_{2}\right)$.

Give some Urea doses has a real effect in plant's height, rod's diameter, and leaves' wide but not significantly different in leaves' number for getting growth and good produce used doses $4.2 \mathrm{~g} / \mathrm{plant}\left(\mathrm{U}_{2}\right)$.

Cannot found different real interactions effected to used Zeolite and Urea in Corn's plant, do a good combination for getting a good result with used Zeolite doses $210 \mathrm{~g} / \mathrm{plot}$ and Urea 4.2 $\mathrm{g} /$ plant $\left(\mathrm{Z}_{2} \mathrm{U}_{2}\right)$.

\subsection{Suggestions}

Recommended to give Zeolite doses $210 \mathrm{~g} / \mathrm{plot}\left(\mathrm{Z}_{2}\right)$ and Urea doses $4.2 \mathrm{~g} / \mathrm{plant}\left(\mathrm{U}_{2}\right)$ on the plateau such as Tanah Karo and need to research a different plant, the height doses, and different areas.

\section{References}

Adamy, I., Husnain \& Rosmimik (2012). Pengaruh Pupuk Organik dari Berbagai Sumber Bahan Baku Terhadap Pertumbuhan Jagung (Zea mays L.) Diterbitkan pada Prosiding Seminar Nasional Teknologi Pemupukan dan Pemulihan Lahan Terdegradasi Bogor, 29-30 Juni 2012. 583-590. http://eprints.upnjatim.ac.id/7864/4/semnas-2012-cvr.pdf

Ademiluyi, B. O., \& Fabiyi, E. P. (2015). Response of hybrid maize (Zea mays) to organic and inorganic fertilizers in soils of South-West and North-Central Nigeria. Int. J. Plant Soil Sci., 7(2), 121-127. https://doi.org/10.9734/IJPSS/2015/16806

Afendi, M. R., Rahayu, A., \& Kardaya, D. (2016). Respons Varietas Jagung (Zea Mays L.) Terhadap Pupuk Berzeolit. Jurnal Pertanian ISSN 2087-4936 Volume 7 Nomor 2, Oktober 2016.

https://www.researchgate.net/publication/320565282_RESPONS_VARIETAS_JAGUNG_Ze a_mays_L_TERHADAP_PUPUK_BERZEOLIT

Al-Jabri, M. (2009). Peningkatan Produksi Tanaman Pangan dengan Pembenah Tanah Zeolit. Balai Penelitian Tanah, Badan Litbang Pertanian, Bogor. http://new.litbang.pertanian.go.id/artikel/230/pdf/Peningkatan\%20Produksi\%20Tanaman

Al-Jabri, M. (2010). Penggunaan Mineral Zeolit Sebagai Pembenah Tanah Pertanian dalam Hubungan Dengan Standardisasinya dan Peningkatan Produksi Tanaman Pangan. Journal of Indonesian Zeolites Vol. 9 No. 1, Mei, Tahun 2010. ISSN 1411-6723. p. 1-12. 
Al-Jabri M., \& R. Soegianto, (2014). Zeolite Technology for Agriculture Development is Very Promising. Prosiding Seminar Nasional Pengembangan Teknologi Pertanian Politeknik Negeri Lampung 24 Mei 2014 ISBN 978-602-70530-0-7. 500-508. https://jurnal.polinela.ac.id/index.php/PROSIDING/article/view/431/298

Ayu Zahrotul Wahidah Winarni, \& Siti Zulaikahdan Abudulloh Fuad, (2007). Dentifikasi Batuan Yang Mengandung Mineral Zeolit Sebagai Ab-Sorbenlogam Berat Berdasarkan Sifat Fisika Batuan Di Desa Kedung Banteng Kecamatan Sumbermanjing Wetan Kabupaten Malang JurusanFisika,FMIPA,UniversitasNegeriMalang(Online) http://jurnalonline.um.ac.id/data/artikel/artikelDA34D76AAA00BF3AAE75FB8484B86438. pdf

Bappenas (2014). Population Projection 2010-2035. Diterbitkan/Published by: Badan Pusat Statistik, Jakarta-Indonesia BPS - Statistics Indonesia. ISBN: 978-979-064-606-3 Pages: 468 https://www.bappenas.go.id/files/5413/9148/4109/Proyeksi_Penduduk_Indonesia_2010-2035 .pdf

Bunyamin, Z., \& Awaluddin. (2013). Pengaruh Populasi Terhadap Pertumbuhan dan Hasil Jagung Semi (Baby corn). Prosiding Seminar Nasional Balai Serealia 2013 di Makassar, p. 214-219. http://balitsereal.litbang.pertanian.go.id/wp-content/uploads/2016/12/3bd13.pdf

Cai, G. X., Chen, D. L., Ding, H., Pacholski, A., Fan, X. H., \& Zhu, Z. L. (2002). Nitrogen losses from fertilizers applied to maize, wheat and rice in the North China Plain. Nutrient Cycling in Agroecosystems, 63, 187-195. https://doi.org/10.1023/A:1021198724250

Erisman, J. W., Sutton, M. A., Galloway, J., Klimont, Z., \& Winiwarter, W. (2008). How a century of ammonia synthesis changed the world. Nat. Geosci., 1, 636-639. https://doi.org/10.1038/ngeo325

Faisal Kasryno, Effendi Pasandaran, Suyamto \& Made O. Adnyana, (2016). Gambaran Umum Ekonomi Jagung Indonesia. Badan Penelitian dan Pengembangan Pertanian, Jakarta. Pusat Penelitian dan Pengembangan Tanaman Pangan, Bogor http://balitsereal.litbang.pertanian.go.id/wp-content/uploads/2016/11/satu.pdf

FAO (2017). The future of food and agriculture - Trends and challenges. Rome. https://www.citibank.com/commercialbank/insights/assets/docs/2018/feeding-the-future.pdf

Goulding, K. W. T. (2016). Soil acidification and the importance of liming agricultural soils with particular reference to the United Kingdom. Published by John Wiley \& Sons Ltd on behalf of British Society of Soil Science Soil Use and Management, September 2016, 32, 390-339. https://doi.org/10.1111/sum.12270

Heard, J. (2004). Nutrient Uptake and Removal Patterns In High Yielding Manitoba Corn Manitoba Agriculture. (http://www.maize.corncob.html) akses 12 Agustus 2019

Kasno, A. (2010). Respon Pemupukan N dan P Untuk Tanaman Jagung. J. Agroteknologi, 13-22.

http://balittanah.litbang.pertanian.go.id/ind/dokumentasi/prosidingsemnas2010/kasno.pdf

Kresnatita, Susi., Koesriharti \& M. Santoso. (2013). Effects of Organic Manure on Growth and Yield of Sweetcorn. Indonesian Green Technology Journal- Universitas Brawijaya 
Malang.

E-ISSN

$2338-1787$

8.

2(1),

8-17.

https://media.neliti.com/media/publications/63427-ID-none.pdf

Kuruseng Haris, Kuruseng Askari Moh. (2008). Pertumbuhan dan Produksi Berbagai Varietas Tanaman Jagung pada Dua Dosis Pupuk Urea. Jurnal Agrisistem. Juni 2008. 4(1).

Kusdarto (2008). Potensi Zeolit di Indonesia. Jurnal Zeolit Indonesia, 7(2), 68-78.

Magdof and Harold Van Es, (2009). Building Soils for Better Cr0ps, Sustainable Soil Management. Hanbook seeries Book 10. By the SARE and USDA. https://www.researchgate.net/publication/242399103_Building_Soils_for_Better_Crops_Buil ding_Soils_for_Better_Crops

Marfuatun (2011). Manfaat Zeolit Dalam Bidang Pertanian Dan Peternakan. Jurusan Pendidikan Kimia fakultas Matematika Dan Ilmu Pengetahuan Alam Universitas Negeri Yogyakarta.

https://media.neliti.com/media/publications/219596-potency-of-zeolite-in-indonesia.pdf

Novizan, (2007). Petunjuk Pemupukan yang Efektif. Agromedia Pustaka. Jakarta.

Nur Aina, Oslan Jumadi, St. Fatmah Hiola. (2017). Respon Pertumbuhan Jagung (Zeamays) dengan Pemberian Urea Bersalut Zeolit Sebagai Nitrogen Lepas Lambat Jurnal Bionature, 18(2), $\quad$ Oktober $2017 \quad 162 \quad$ ISSN $1411-4720, \quad 152-162$. https://doi.org/10.35580/bionature.v18i2.6146

Polat, E., Karaca, M., Demir, H., \& Onus, A. N. (2004). Use of Natural Zeolite (Clinoptilolite) In Agriculture. Journal of Fruit and Ornamental Plant Research, 12(1), 183-189.

Rasyid, B. (2012). Aplikasi Kompos Kombinasi Zeolit dan Fosfat Alam Untuk Peningkatan Kualitas Tanah Ultisol dan Produktivitas Tanaman Jagung. Jurnal Agrisistem, Juni 2012, 8(1). http://repository.unhas.ac.id/handle/123456789/7256

Sabilu, Y. (2016). Aplikasi Zeolit Meningkatkan Hasil Tanaman Pada Tanah Ultisol Biowallacea, Vol. 3 (2), Jurusan Biologi FMIPA, Universitas Halu Oleo, Kendari, 396-407. http://ojs.uho.ac.id/index.php/wallacea/article/downloadSuppFile/3236/161

Saragih, D., Herawati Hamim \& Niar Nurmauli. (2013). Pengaruh Dosis dan Waktu Aplikasi Pupuk Urea dalam Meningkatkan Pertumbuhan dan Hasil Jagung (Zea mays L.) Pioneer 27. J. Agrotek Tropika. ISSN 2337-4993, 1(1), 50-54. Januari 2013. https://docplayer.info/44159376-Pengaruh-dosis-dan-waktu-aplikasi-pupuk-urea-dalam-m

Sembiring, S., Riduan, S., Seringena, br K. (2017). Zeolite and Urea Fertilizer in the Growth and Yield of Maize. Quest Journals, Journals of Research in Agriculture and Animal Science, 4(9), 14-24 ISSN (Online): 2321-9459. www.questjournals.org

Sembiring, S., Riduan, S., Seringena, br K. (2016). Budidaya Tanaman Jagung Dengan Pemberian Ziolit. CV. Monora-Medan. p. 2.

Setyo, B., \& Sasmita, S. (2015). Ilmu Dan Implementasi Kesuburan Tanah. UMM Malang http://elibrary.polbangtanmalang.ac.id/index.php?p=show_detail\&inXML=true\&id=4

Sutedjo, M., M. (2002). Pupuk dan Cara Pemupukan. PT. Rineka Cipta. Jakarta. p.7-8. https://onesearch.id/Author/Home?author=SUTEDJO\%2C+Mul+Mulyani 
Sutedjo, M., M. (2008). Pupuk dan Cara Pemupukan. Penerbit Renika Cipta. Jakarta. https://onesearch.id/Author/Home?author=SUTEDJO\%2C+Mul+Mulyani

Suwardi. (2009). Technique Of Zeolite Application On Agricultural As A Soil Ameliorant. Journal of Indonesia Zeolites, 8(1). Mei 2009. ISSN: 1411-6723, 33-38. https://media.neliti.com/media/publications/219453-none.pdf

Suwandi (2006). Penggunaan Zeolit Di Bidang Pertanian. Prosiding Seminar Nasional Zeolit V, Bandar Lampung. ISBN $\quad$ 979-15213-0-1, 30-39. https://izindo.files.wordpress.com/2013/02/prosiding-lampung.pdf

Syafruddin, (2015). Management of Nitrogen Fertilizer Application on Maize.Balai Penelitian Tanaman Serealia. Maros. Indonesia. https://ejurnal.litbang.pertanian.go.id

Tuherkih, E., \& Sipahutar, I. A. (2008). Pengaruh Pupuk NPK Majemuk (16:16:15) Terhadap Pertumbuhan dan Hasil Jagung (Zea Mays L) Di Tanah Inceptisols. Balai Penelitian. Tanah 77-88.

http://balittanah.litbang.pertanian.go.id/ind/dokumentasi/prosidingsemnas2010/enggis \%20\% 2077-90.pdf

Widyanto. A., Sebayang. H. T., \& Soekartomo, S. (2013). The Effect Of Zeolite Application And Urea Fertilizer On Growth And Result Of Sweet Corn (Zea mays L. saccharata Sturt.) Jurnal Produksi Tanaman, 1(4). (2013) ISSN: 2338-3976 |E-ISSN: 2527-8452. p.378-388. https://www.neliti.com/id/publications/126550/pengaruh-pengaplikasian-zeolit-dan-pupuk-ur ea-pada-pertumbuhan-dan-hasil-tanaman

Wang, G., Chen, X., Cui, Z., Yue, S., \& Zhang, F. (2014). Estimated reactive nitrogen losses for intensive maize production in China. Agriculture. Ecosystems. Environment. 197, 293-300. https://doi.org/10.1016/j.agee.2014.07.014

Winarni, A. Z., Wahidah, S. Z., \& Abudulloh, F. (2007). Identifikasi Batuan Yang Mengandung Mineral Zeolit Sebagai Absorben Logam Berat Berdasarkan Sifat Fisika Batuan Di Desa Kedung Banteng Kecamatan Sumbermanjing Wetan Kabupaten Malang. Jurusan Fisika, FMIPA, Universitas Negeri Malang. http://jurnalonline.um.ac.id/data/artikel/artikelDA34D76AAA00BF3AAE75FB8484B86438. pdf

Yateman Arryanto, Suwardi, Husaini, Toha Affandi, Siti Amini, M. Al-Jabri, Pollung Siagian, Dyah Setyorini, Arif Rahaman, dan Yuni Pujiastuti. (2012). Zeolite dan Masa Depan Bangsa. Road Map "Revitalisasi Peranan Zeolit Alam dalam Ketahanan Pangan dan Kedaulatan Bangsa. Ikatan Zeolit Indonesia (IZI). ISBN 602-98165-6-x

\section{Copyright Disclaimer}

Copyright for this article is retained by the author(s), with first publication rights granted to the journal.

This is an open-access article distributed under the terms and conditions of the Creative Commons Attribution license (http://creativecommons.org/licenses/by/4.0/). 